Mauro Perani

\title{
The Corpus Epitaphiorum Hebraicorum Italiae (CEHI): A Project to Publish a Complete Corpus of the Epitaphs Preserved in Italian Jewish Cemeteries of the Sixteenth-Nineteenth Centuries
}

Les cimetières sont remplis de personnes indispensables

\section{Introduction}

Italy's Jewish cultural heritage is one of the most important in the western world. For geographical and historical reasons, the Jewry of the Italian peninsula is the most ancient in Europe and the Mediterranean basin. The presence of Jewish communities in Rome, Sardinia and the southern region of Apulia and Sicily goes back two thousand years, dating from the first years of the Christian era, and even earlier in the case of Rome. Although Italian Jewry, compared with other European countries, never achieved high numbers, it always played a major role because of its cultural importance, and due to a successful co-existence on Italian soil of the three major cultural and geographical European traditions: the Italian, the Sefardi and the Ashkenazi. As has commonly occurred in the field of non-Jewish culture, Italy has also produced about half of all resources in the field of Jewish cultural heritage, and the relevant treasures are today kept in Jewish and non-Jewish museums and libraries all over the world, as well as in the Italian Peninsula. Italian Jewish inscriptions play an important role in this rich legacy, with regard to both the first 1,540 years of the current era, predominantly in southern Italy, and the cemeteries of the Italian Jews between the sixteenth and nineteenth centuries. From the sixteenth century onwards, and well into the seventeenth century, the art of writing epitaphs in Hebrew became a true literary genre, practised in rhyme and rhythm, by rabbis and learned scholars. The writing of these texts was commissioned by people requesting epitaphs for their dead relatives, as well as for literary and fictional purposes. We have to take into account that the epitaphs - sometimes more and sometimes less artistically elaborated constituted, starting in the sixteenth century, the first registration of people, in both the Christian and the Jewish worlds. They were therefore equally 


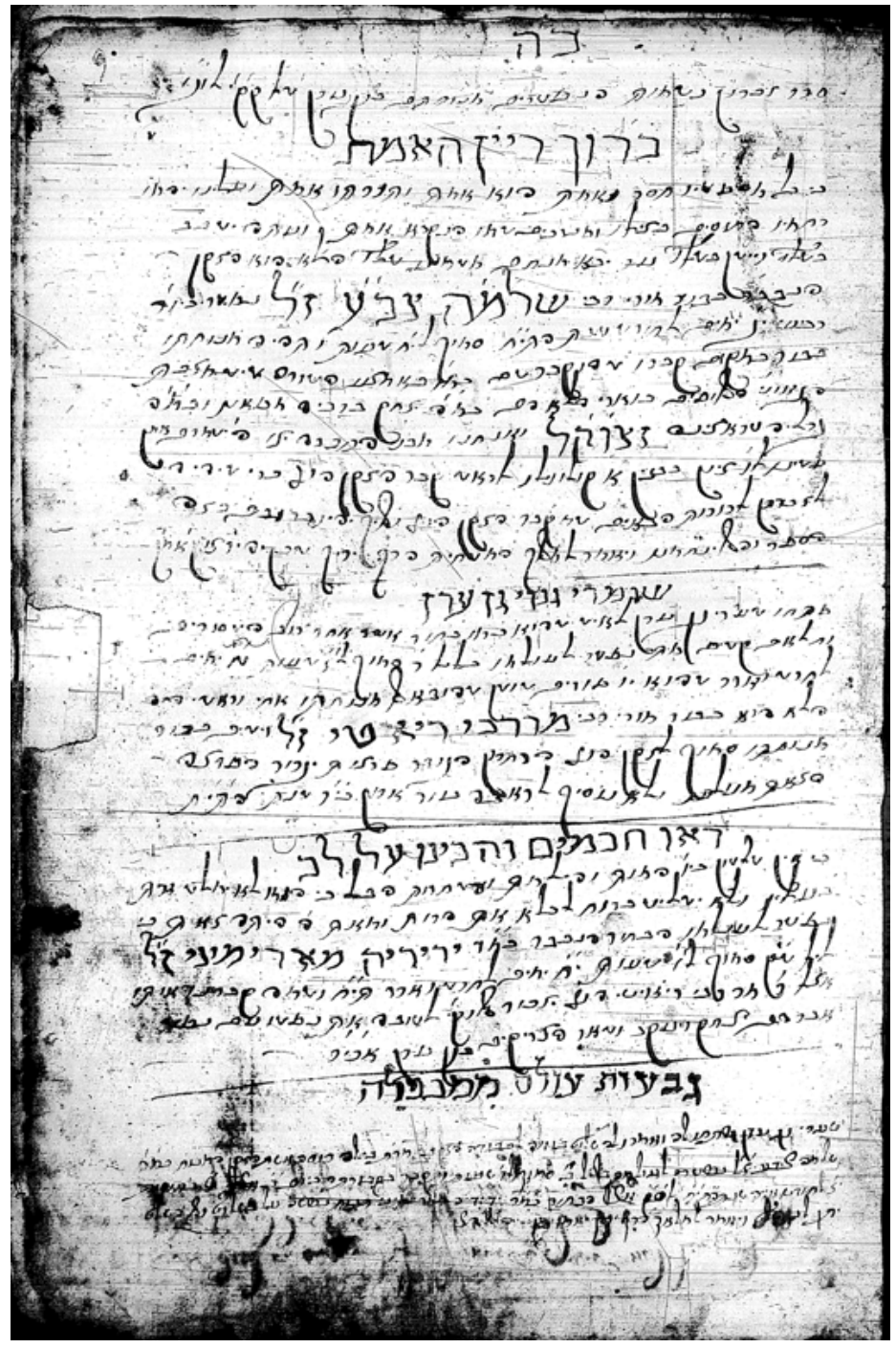

Fig. 1: The first page (fol. 9r) of the Pinqas Ha-Niftarim of the Jewish Community in Lugo, recording its deaths and ranging from 1658 to 1825; Ms. n. 3960, of the Jewish Theological Seminary in New York. The first record belongs to Shelomo Șeva', who passed away on 4

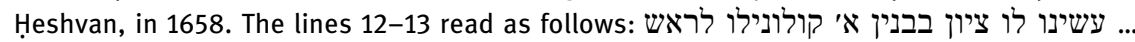

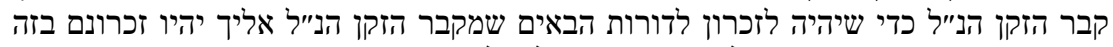

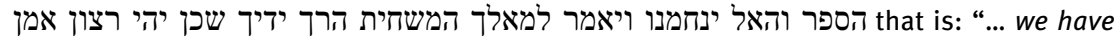
made for him a colonnello [pillar] as sign to indicate the tomb of this old man, as an everlasting memory for all those who in future generations, from the tomb of this old man forward, are to be recorded in this book, and God will console us and will tell the exterminating Angel: 'Loosen your hand', and so be it, amen". 


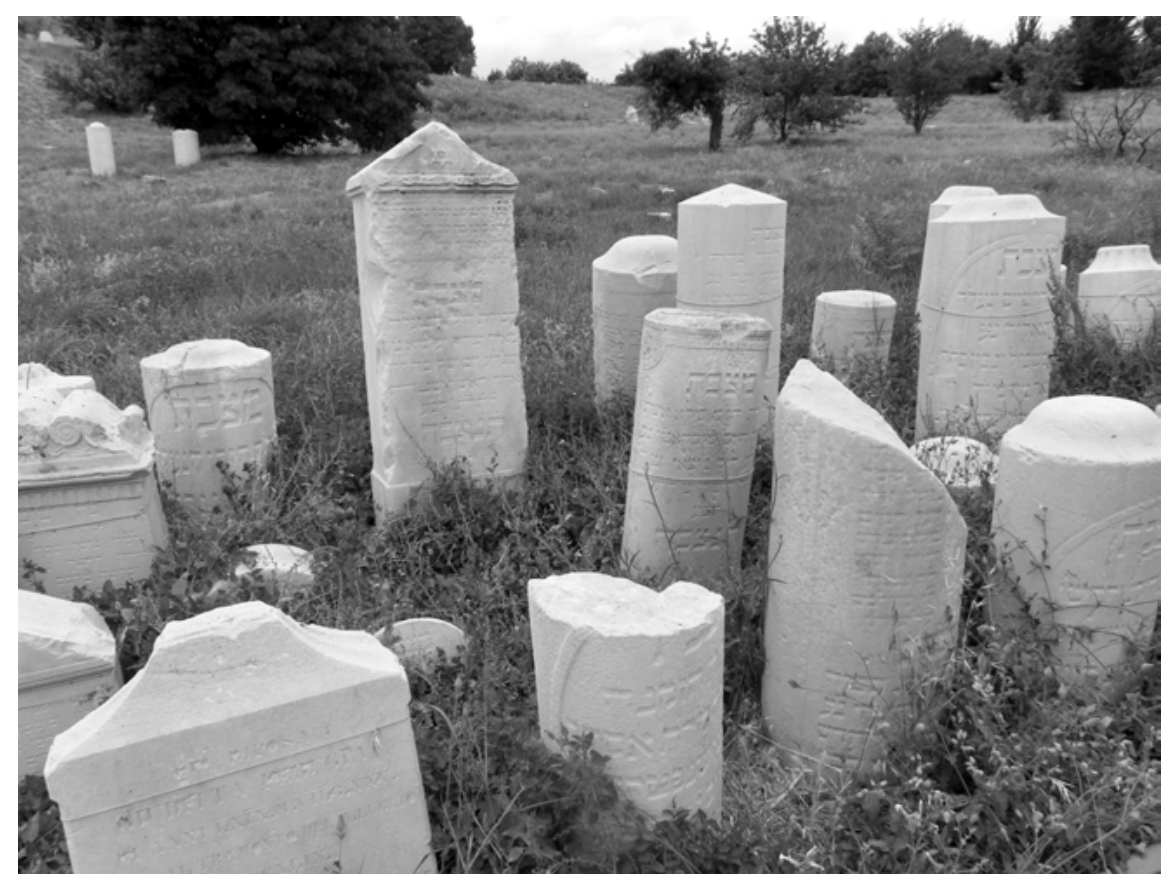

Fig. 2: Tombstones at the Jewish cemetery of Cardeto in Ancona, in the shape of cylindrical pillars, made from erosion resistant Istria stone and therefore in a good state of preservation. This cylindrical style probably originated in northern Africa and was adopted by Sefardi Jews. After the expulsion, this tombstone style, brought to this region by Jews from Sefarad and from Turkey, became almost unique among the Marches communities.

important as compilations of births, marriages and deaths, written and archived by priests and rabbis. In the Christian world this practice was formally imposed on all parish priests in the middle of the fifteenth century by the Council of Trent, and implemented during the second half of that century. At the same time, the Jewish communities of Italy started to write minutes of the council assemblies and to compile registers of dead Jews. A very interesting example is found in the Pinqas Ha-Niftarim (פנקס הנפטרים), Ms. 3960, of the Jewish Theological Seminary in New York, comprising eighty-three folios of the Jewish hevra qaddisha (burial society) of the town of Lugo. This charitable body was charged by the Jewish community to bury its dead and the manuscript contains the death records of almost two centuries, from 1658 until 1825 (Fig. 1). I shall later present an example of the importance of cross-checking information from different sources so as to enrich our knowledge not only of the active Jewish communities of Italy, but also of their death, burial and mourning liturgy in the early modern period. Because the tombstones are 
mostly made from less solid stone than the pietra d'Istria, that is particularly used in the Jewish cemeteries of the Marches region (Fig. 2), this cultural heritage has in the course of the past fifty years been more severely damaged by air pollution and acid rain than in the previous five centuries. Immediate action is required to save this precious heritage and to avoid the legacy being irremediably lost for future centuries and generations. Several Jewish mașevot are already almost impossible to decipher, and consequently lost forever. It should not be forgotten that the texts of the epitaphs have the potential to make an important contribution to our knowledge of Hebrew epigraphy in Italy and the western Jewish civilization as a whole.

\section{The Italian Jewish inscriptions of the first millennium and until 1540 CE}

The work carried out by my late friend, Professor Cesare Colafemmina, is of great importance for Italian inscriptions of this period. Professor Colafemmina has published for the first time numerous southern Italian inscriptions, some discovered by himself, as is the case in the matter of the inscriptions found in the catacombs of Venosa. Unfortunately, these articles were published in various Italian reviews and journals which remain difficult of accession. The corpus includes catacomb inscriptions painted or engraved on the plaster of arcosolia, as in Jewish catacombs of Sant'Antioco (Fig. 3), in Sulcis region of southern Sardinia, dating back to the late Roman period (fourth-fifth century CE). The Hebrew epigraphy of Sicily, the Venosa sepulchral inscriptions on stone in the Basilicata Region, and similar inscriptions in Apulia, Calabria, and other southern Italian regions, provide data until 1540, which is the starting-point for the documentation then coming from the Jewish cemeteries of central and northern Italy. The inscriptions from the third to the seventh centuries were mainly published by Jean Baptiste Frey in his Corpus inscriptionum iudaicarum. Recueil des inscriptions juives qui vont du IIIe siècle avant JésusChrist au VII ${ }^{e}$ siècle de notre ère, in Rome, Pontificio Istituto di Archeologia Cristiana, 1936. More recently, David Noy published two volumes: Jewish Inscriptions of Western Europe: Volume 1, Italy (excluding the City of Rome), Spain and Gaul, Cambridge University Press, 1995, and Jewish Inscriptions of Western Europe: Volume 2, The City of Rome, Cambridge University Press, 1995. For Italy, Noy based himself mainly on Colafemmina's studies. The main studies by Colafemmina are listed hereunder, with only one of them, no. 23, appearing in English. For this reason, following an invitation received some 


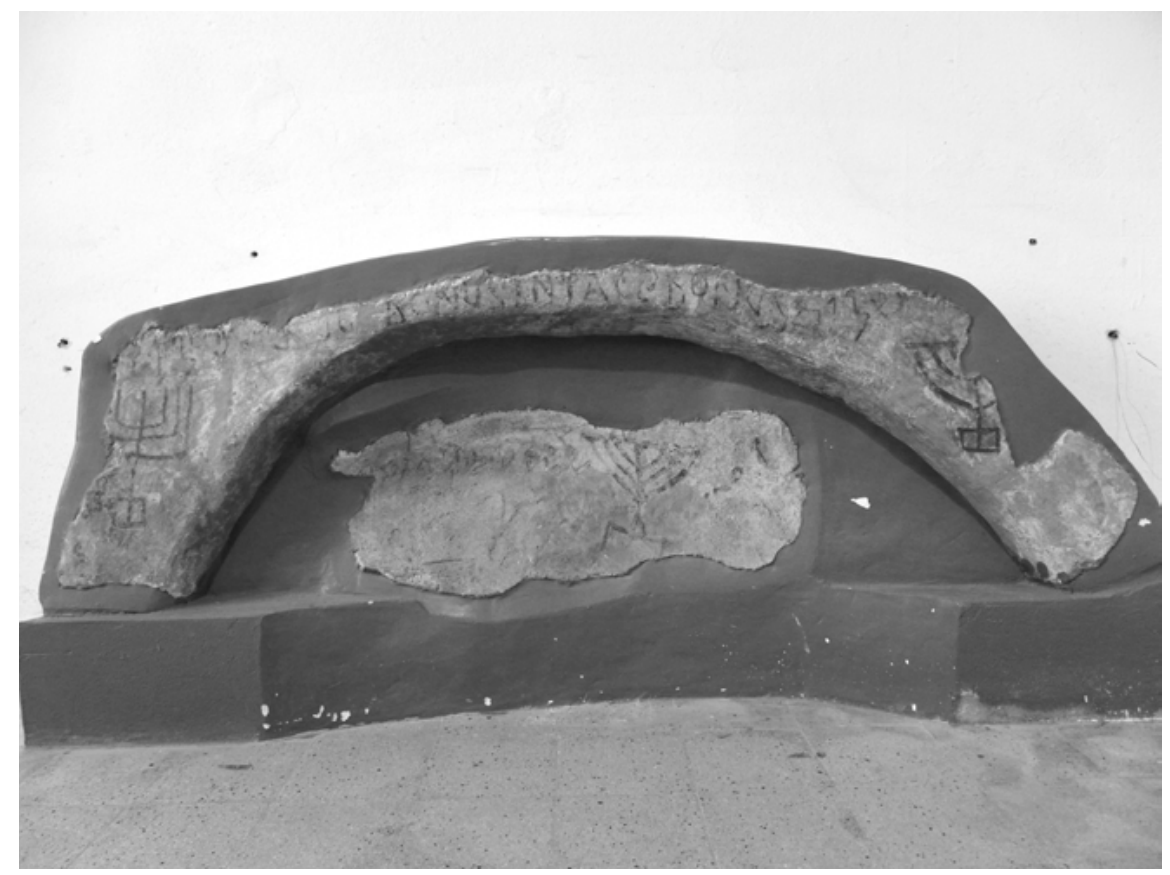

Fig. 3: Inscriptions in Hebrew and Latin, discovered in 1894, in the Jewish catacomb of Bonus, Roman period, ( $4^{\text {th }}-5^{\text {th }}$ centuries), at Sant'Antioco, in southern Sardinia. During the restoration of the two arcosolia of Bonus and Beronice, about 40 years ago, the restorer wrongly placed the inner painted menorah and inscription of Beronice's arcosolium under the arch of the arcosolium of Bonus (this image) and vice versa. In the upper arc, on the right, we read shalom, and in the inscription of the central part, to the left of the menorah, is clearly readable: shalom 'al [...] whereas the other words, probably incorrectly reconstructed, are difficult to decipher; they perhaps mean: [mishkavo amen], according a well known formula.

time ago from Colette Sirat, the general editor of this Jewish series, I very much hope that we can soon see the republication of all Italian epigraphs of the first 1.500 years of the common era in one English volume in the prestigious series Monumenta Palaeographica Medii Aevi: Series Hebraica (SHEBA) printed by Brepols in Turnhout (Belgium) whose policy is to publish originalsize facsimiles of the documentary heritage of Europe. 


\section{Studies by Cesare Colafemmina of the Italian Hebrew inscriptions}

1. 'Di alcune iscrizioni giudaiche di Taranto', in Studi di storia pugliese in onore di Giuseppe Chiarelli, ed. by Michele Paone (Galatina: Mario Congedo, 1972), I, pp. 233-42.

2. 'Un'iscrizione ebraica inedita di Trani', in Augustinianum, 13 (1973), pp. 339-43.

3. 'Iscrizioni ebraiche a Brindisi', in Brundisii res, 5 (1973), pp. 91-106.

4. 'Documenti epigrafici inediti o mal noti della "Regio Secunda", in Cenacolo, 3 (1973), pp. 147-151, figg. 1-5.

5. 'Nova e vetera nella catacomba ebraica di Venosa', in Studi storici, ed. by Cesare Colafemmina (Molfetta: Ecumenica Editrice-, 1974), pp. 87-94, tab. I-IV.

6. 'L'iscrizione brindisina di Baruch ben Yonah e Amittai da Oria', in Brundisii res, 7 (1975), pp. 295-300.

7. 'Nuove iscrizioni ebraiche a Venosa', in Studi in memoria di p. Adiuto Putignani (Cassano M.: Ecumenica Editrice, 1975), pp. 41-46, tab. XII-XV.

8. 'Di una iscrizione greco-ebraica di Otranto', in Vetera Christianorum, 12 (1975), pp. 131-37.

9. 'Iscrizioni paleocristiane di Venosa', in Vetera Christianorum, 13 (1976), pp. 149-65.

10. 'Gli ebrei a Taranto nella documentazione epigrafica (secc. IV-X)', in La Chiesa di Taranto, I: Dalle origini all'avvento dei Normanni, ed. by C. D. Fonseca (Galatina: Congedo Editore, 1977), pp. 109-27.

11. 'Un'iscrizione venosina inedita dell'822', in La Rassegna Mensile d'Israel, 43 (1977), pp. 261-63.

12. 'Di un'iscrizione biblica (Ps. 125,1) e di altri graffiti', in Il santuario di S. Michele sul Gargano dal VI al IX secolo. Contributo alla storia della Langobardia meridionale. Proceedings of the congress held in Monte Sant'Angelo (9-10 dicembre 1978), ed. by Carlo Carletti and Giorgio Otranto (Bari: Edipuglia, 1980), pp. 337-45, figs. 1-6.

13. 'Una nuova iscrizione ebraica a Venosa', in Vetera Christianorum, 21 (1984), pp. 197-202.

14. 'Iscrizione ebraica inedita di Lavello', in Vetera Christianorum, 23 (1986), pp. 171-76.

15. 'Tre nuove iscrizioni ebraiche a Venosa', in Vetera Christianorum, 24 (1987), pp. 201-209.

16. 'Note su di una iscrizione ebraico-latina di Oria', in Vetera Christianorum, 25 (1988), pp. 641-51. 
17. 'Le iscrizioni ebraiche nel cimitero di Tarsia', in Ferramont: un lager nel Sud', in Proceedings of the International congress held in Cosenza (15-16 maggio 1987), ed. by Francesco Volpe (Cosenza: Edizioni Orizzonti Meridionali, 1990), pp. 101-17.

18. 'Una nuova epigrafe ebraica altomedievale a Lavello', in Vetera Christianorum, 29 (1992), pp. 411-21.

19. 'Epigraphica Hebraica Venusina', in Vetera Christianorum, 30 (1993), pp. 411-21.

20. 'Due nuove iscrizioni sinagogali pugliesi', in Vetera Christianorum, 21 (1994), pp. 383-95.

21. 'Iscrizioni ebraiche su una lucerna e su un amuleto rinvenuti nel Salernitano', in Apollo. Bollettino dei Musei Provinciali del Salernitano, 10 (1994), pp. 56-58.

22. 'Ipogei ebraici in Sicilia', in Italia judaica. Gli ebrei in Sicilia sino all'espulsione del 1492, Proceedings of the V congress held in Palermo (15-19 giugno 1992), Publications of the Archivi di Stato, Saggi, 32 (Rome: Ministero per i Beni Culturali e Ambientali, 1995), pp. 304-29.

23. 'Hebrew Inscriptions of the Early Medieval Period in Southern Italy', in The Jews of Italy. Memory and Identity, ed. by Barbara Garvin and Bernard Cooperman, Studies and Textes in Jewish History and Culture, 7 (Bethesda: University Press of Maryland, 2000), pp. 65-81.

24. 'Un frammento di iscrizione ebraica sinagogale', in Palazzo Adorno. Storia e restauri, ed. by Regina Poso (Matera; Spolent: R\&R Editrice), 2000, pp. 24-29.

25. 'Di alcune iscrizioni ebraiche a Trani', in La Rassegna Mensile d'Israel, 67 (2001), pp. 305-312.

26. 'Nota sull'iscrizione ebraica rinvenuta nella chiesa di S. Giovanni Battista a Siracusa', in A. Scandaliato and N. Mulè (eds.), La sinagoga e il bagno rituale degli ebrei di Siracusa, con una nota epigrafica di Cesare Colafemmina, Associazione Italiana per lo Studio del Giudaismo, Testi e Studi dell'AISG n. 13 (Florence: Giuntina, 2002), pp. 129-33.

27. 'Le catacombe ebraiche nell'Italia meridionale e nell'area sicula: Venosa, Siracusa, Noto Lipari, Malta', in M. Perani (ed.), I beni culturali ebraici in Italia. Situazione attuale, problemi e progetti per il futuro, Proceedings of the Congress of Ravenna (22-24 maggio 2001) (Ravenna: Longo editore, 2003), pp. 119-46.

28. 'Le testimonianze epigrafiche e archeologiche come fonte storica', in Materia giudaica IX/1-2 (2004), pp. 37-52.

29. 'Tre iscrizioni ebraiche altomedievali a Matera', in M. Perani (ed.), Una manna buona per Mantova. Man Tov le-Man Tovah. Studi in onore di Vittore Colorni per il suo $92^{\circ}$ Compleanno (Florence: Olschki, 2004), pp. 101-14. 
30. 'Sull'iscrizione di Berakah ben Sa'adyah Ha-Zaqen Faqqas di Siracusa', in Materia giudaica X/2 (2005), pp. 313-17.

31. 'Una rilettura delle epigrafi ebraiche della Sardegna', in C. Tasca (ed.), Gli ebrei in Sardegna nel contesto mediterraneo. La riflessione storiografica da Giovanni Spano ad oggi, Atti del XXII Convegno Internazionale dell'AISG, published in Materia giudaica, XIV/1-2 (2009), pp. 81-99.

\section{The new series Corpus Epitaphiorum Hebraicorum Italiae (CEHI) of the sixteenth-nineteenth centuries}

For the reasons already noted, and particularly because of the precarious state of preservation of the epitaphs of the past four centuries on the massevot of Italian Jewish cemeteries that may be lost forever, I decided to set up a project whose aim is the publication of all the funerary texts of Jewish tombstones in Italy. The research material is mainly located in the central and northern regions of Italy. In southern Italy in the modern era there are no Jewish cemeteries because of the expulsion of the Jews from these lands during the Gerush Sefarad of 1492, that stretched as far as Sardinia and Sicily, and included the sixteenth-century reign of Naples and other kingdoms. On the other hand, as already pointed out, southern Italy holds almost all the Hebrew epigraphic documentation of the first 1,500 years of the current era.

This precious heritage of texts written on stone must not be lost but should be archived and published, also on the Internet, so that it can be preserved for and available to future generations. This is exactly the aim of the newly established Series of CEHI, published by La Giuntina Press in Florence, where the whole corpus of Jewish epitaphs extant in all the Jewish cemeteries of Italy will be gathered and published. As pointed out earlier, the series will not include the corpus of the Jewish inscriptions of the first millennium before 1540, found predominantly in the regions of southern Italy, and almost entirely already published. The volumes of the CEHI Series Project are each devoted to a particular cemetery or to several small cemeteries in the same area. They include editions of the Hebrew texts of the epitaphs, the identification of biblical sources and rabbinic quotations, with explanatory notes and an Italian translation.

Each cemetery will have an introduction to its local Jewish community and its history, in order to contextualize the funerary inscriptions against their 
historical background. In addition, a rich apparatus of colour and black/white images will illustrate the editions of the texts. An online edition on a website will be created and developed in parallel, to complement the printed hard copy, presenting the content of each volume and allowing for an online electronic search of the names of Jews, both in Hebrew and in Italian. Under my supervision, the project, beginning with a survey of the status quaestionis and of research in cooperation with the Fondazione per $i$ Beni Culturali Ebraici and the Unione delle Comunità Ebraiche Italiane (UCEI, Union of Italian Jewish Communities), and covering the period from the sixteenth to the nineteenth centuries, aims at producing a census of all the Jewish cemeteries in Italy. Each cemetery has been catalogued on electronic cards that show the state of preservation, list the existing studies, refer to the related Jewish communities, and include maps of geographic locations, a complete bibliography, digital photographs of the epigraphs, with comments on their state of conservation and legibility. During the past ten years, I have assigned a number of MA and BA dissertations to research on the following cemeteries of the Emilia Romagna and Marches regions: Lugo, Ancona, Senigallia, Pesaro, Correggio, Finale Emilia, Cento. Each of these studies contains an introduction on the Jewish communities, a description of each site with historical notes, and details of the social institutions and structures that have characterized the communities over the centuries. They also deal with the reasons for their foundation and their subsequent history, as well as tracing the development of their cemeteries over the centuries, and often also the reasons for their disappearance. These dissertations include transcriptions of the sepulchral inscriptions found, their Italian versions, and photographic reproductions. The whole process is then completed with indices of names and places in Italian and Hebrew. As far the research methodology is concerned, the first step required an inspection of the Jewish cemeteries under examination, in order to ascertain the condition of the epitaphs, which were often in a bad state of preservation, many of them destroyed by overgrown vegetation and the neglect that characterizes numerous Jewish cemeteries. During the inspection, the tombstones were partially cleaned by the removal of plaque, moss, lichen and grimy patina. Through these efforts, fragments of accidentally damaged and overgrown gravestones have been recovered as far as possible, Jewish epitaphs have been made legible, and have thus reclaimed their importance as documents, testifying to the history of the Jewish communities that have, over time, populated that place. 


\section{Planning of the series CEHI}

The Corpus Epitaphiorum Hebraicorum Italiae was inaugurated in September 2008 with the publication of the first volume entitled: Il 'giardino' degli ebrei. Cimiteri ebraici del Mantovano, edited by La Giuntina Press, in Florence. The volume brings together about two years of research on the cemeteries of Mantua and the Mantovano and includes the Jewish cemeteries of Mantua, Bozzolo, Gazzuolo, Ostiano, Pomponesco, Revere, Rivarolo Mantovano, Sabbioneta, Sermide and Viadana1. Two new volumes, devoted to the cemeteries of Lugo and Finale Emilia, have been published at the beginning of 2011.

The volumes already published are:

1. Il 'giardino' degli ebrei. Cimiteri ebraici del Mantovano, ed. by C. Bonora Previdi and A. Mortari, CEHI n. 1 (Florence: La Giuntina, 2008).

2. M. Perani, A. Pirazzini and G. Corazzol, Il cimitero ebraico di Lugo, CEHI n. 2, (Florence: La Giuntina, 2011).

3. M. P. Balboni, M. Perani, A. Creatura, Sigilli di eternità. Il cimitero ebraico di Finale Emilia, n. 3 (Florence: La Giuntina, 2011).

The following volumes are scheduled to be published in the coming years:
4. Padova
5. Senigallia
6. Ancona
7. Pesaro
8. Urbino
9. Triveneto
10. Venice

The volumes next listed are already planned for following years:
11. Correggio
12. Roma
13. Cento
14. Bologna

And at a later date attention will be given to the Jewish cemeteries of: Modena, Ferrara, Pisa, Asti, Perugia, Vercelli, and whatever else is extant in the Italian regions of Piedmont, Umbria, Tuscany, Lombardy.

1 I have published additional material but I am unable to include it in this article; see Addenda ai cimiteri ebraici di Mantova e di Rivarolo Mantovano e l'epitaffio incompiuto del Museo Ebraico di Bologna, in Materia giudaica, 13/1-2 (2008), pp. 281-99. 


\section{The information contained in the text of the epitaphs and their importance for the new science of genealogy}

The valuable documentation obtained from the epitaphs constitutes a sort of archive written on stone, yielding important information about family relations and other, sometimes rather explicit details, often almost impossible to find in official historical sources, such as the causes of death. The epitaphs tell stories of fathers, mothers, brothers and sisters, sons and daughters. They provide interesting insights into such causes of death: as child-bearing, a bad cold, etc. Most interestingly, the epitaph represents a more popular documentation that is not related exclusively to riches, power and communal importance. The epitaphs retrace Jewish genealogy and are of importance for the relatively new academic discipline of genealogical research. This 'registration', 'engraved on stone' was the first to be extended to all the people, regardless of their social background. In previous centuries, with archival documentation starting basically in the thirteenth and fourteenth centuries, the sources related primarily to rich and important people: scholars, leading rabbis, and bankers. The poor, both of the Jewish and Christian communities, had less relevance and were often neither registered nor formally archived. Historical documents are in fact rarely representative of the history of the common people, but more commonly records of the rich and powerful, of princes, popes, the leading classes, bankers and merchants. Officially registering the dates of circumcision or baptism, and extending this process even to those of low social rank, and reporting marriages, deaths and other events in their daily lives, represented an important turning point in the drive towards a certain democratization in the production of historical documents. Although it remains true that the most beautiful and artistically and literarily valuable mașevot and epitaphs are those composed for important people, they do nevertheless also reveal some general information on the lower ranks of society. It is from these epitaphs that I gleaned pieces of information that enabled me to reconstruct the puzzling genealogy of some families, such as the Fano or Forlì households, as documented in the Jewish cemetery of Lugo. I achieved this by combining the data from the epitaphs with the above-mentioned register of deaths diligently compiled for about two hundreds years by scribes of the hevra qaddisha charged with the task of burying the dead. 


\section{Incorrect and misleading conservation work that has damaged the inscriptions}

During my research on the Italian Jewish cemeteries, I have, more than once, discovered Hebrew texts that have been rewritten in black paint by someone with little or no command of Hebrew, in an attempt to save the epitaphs that has unintentionally had the opposite effect. This practice not only ruins the tombstone, but more frequently also damages the text, since those rewriting it have not understood the meaning of the epitaph, which is often in poetry or in the exalted language of past centuries, from Baroque until the Ottocento. Among these attempts at preservation, I have found many exchanges of similar-looking Hebrew letters such as, for example, zayin for waw, kaf for bet, he for het or vice versa, and others. Zealous and well-meaning volunteers, taking care of the cemetery and its maintenance, while acting in good faith, have caused serious damage. Those erroneous corrections, or the confusion of Hebrew letters and words, have meant that tremendous effort and time have been required to read and decipher the (original) text, often much more than would have been necessary to decipher and translate the epitaphs in their original (albeit poor) state of preservation. In other cases, I noted that the masevot had been cleaned by using a muriatic acid solution and wire brush, which seriously abrased and damaged the stone, erasing forever the traces of engravings, that had suffered the continuous erosions of time and weather. Here, I wish also to add that in Italy there are many Jewish cemeteries in places from which Jewish communities have long since disappeared, and it has often been Christians who have preserved these artefacts and their cultural heritage. It may appear strange to the large Jewish communities of the United States or Israel that in Italy and other European countries Jewish studies are pursued mainly by non-Jewish scholars. It is also a sad fact that Italy, a country richer than most in cultural heritage, whether Jewish or non-Jewish, invests less than many other countries in its conservation. In addition, there are absurd laws that prevent the protection and preservation of Jewish cemeteries. In Mantua, for example, a city where the Jewish population in the sixteenth century reached ten per cent, the municipality, to this very day, cannot supply (or support) a custodian for the Jewish cemetery, since the cemetery is not situated on public land but on land owned by the Jewish community. This is, in a way, an act of discrimination against the Jewish citizens of Mantua who for centuries paid their taxes like everyone else. 


\section{A diwan of poetry in rhyme and rhythm}

Starting from the sixteenth century, and in particular during the Baroque period, the writing of poems and epitaphs in rhyme and rhythm became an accepted literary mode. As Michela Andreatta has shown in her article on the Jewish epitaph as literary genre, ${ }^{2}$ it was the rabbis and leading scholars who, in these centuries, wrote collections of sepulchral inscriptions either for themselves, or as commissioned by others. Epitaphs, both true and fictitious, were worthy of publication as poetry. This precious heritage certainly must be saved from decline and falling into oblivion. A device used by the Jewish poets who composed these piyyutim is the separation of two parts of a word for poetical reasons. There follow a few examples of such poems.

A fine poetical composition is found in epitaph no. 9 from the cemetery of Lugo, written for Refael Hiizqiya of Forlì, who passed away in 1592 (Fig. 4). The text is structured according a metrical scheme in octave: $\mathrm{AB}, \mathrm{AB}, \mathrm{AC}, \mathrm{AC}$, where $\mathrm{A}$ ends in -ìm, $\mathrm{B}$ in -èreș and $\mathrm{C}$ in -arùș. As a matter of fact, the beauty and rhetoric of these poems can be appreciated only in their original Hebrew.

Hebrew text:

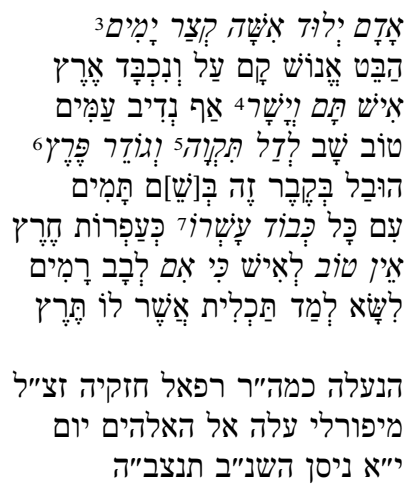

2 M. Andreatta, L'epitaffio come genere letterario, in Il 'giardino' degli ebrei: Cimiteri ebraici del Mantovano, ed. by A. Mortari and C. Bonora Previdi, series Corpus Epitaphiorum Hebraicorum Italiae (CEHI), created and directed by Mauro Perani, n. 1 (Florence: Giuntina, 2008), pp. 9-23.

3 Job 14:1.

4 Job 1:8.

5 Job 5:16.

6 Isa 58:12.

7 Esth 5:11. 


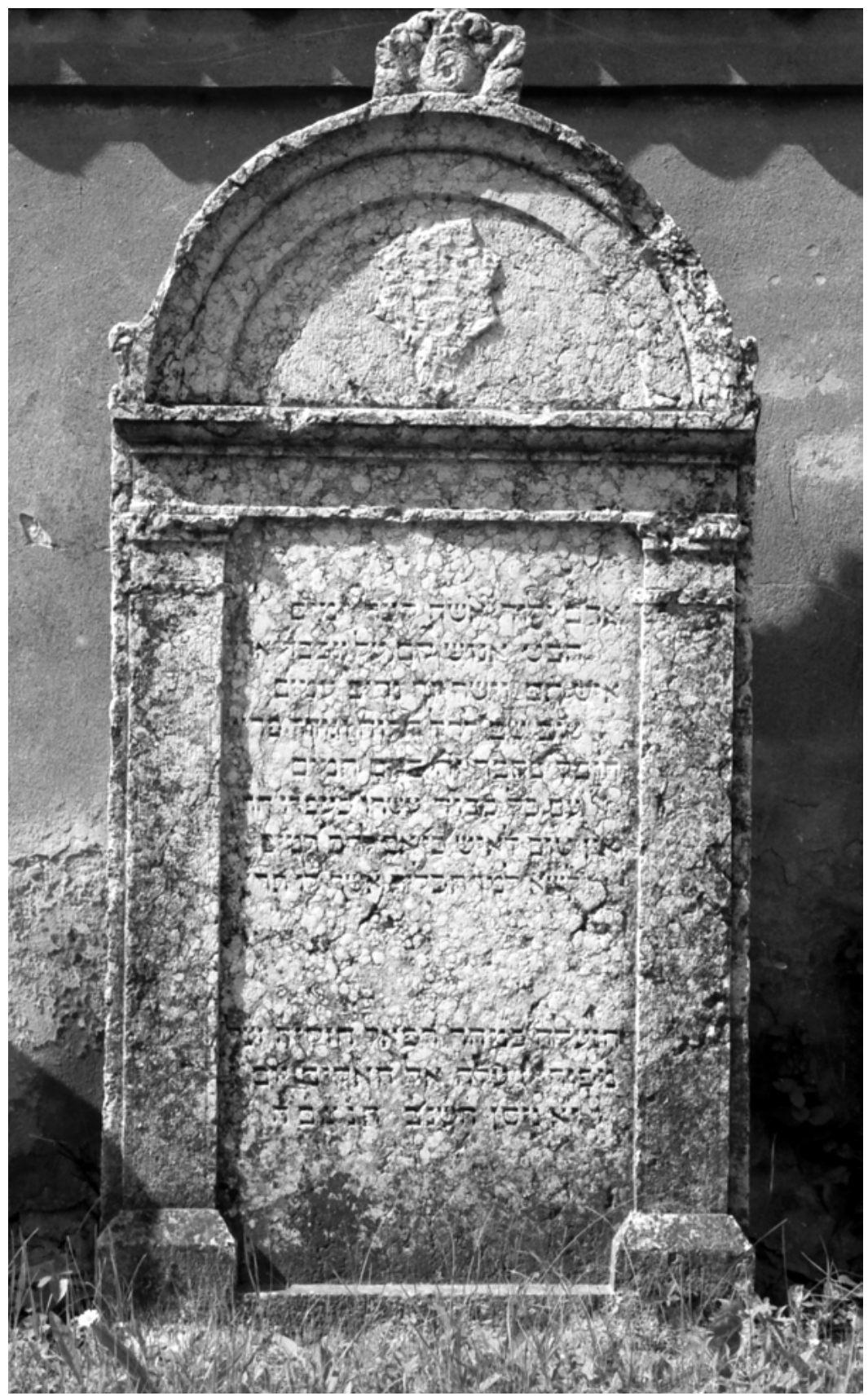

Fig. 4: Tombstone in the Jewish cemetery of Lugo with epitaph of Refael Ḥizqiya from Forlì, who passed away in 1592. 
English version:

Poetic part:

1. Short is the life of man born of woman (Job 14:1).

2. Regard a fine man who is high among the nobles of the land.

3. A man right and just (Job 1:8), a true prince of the nations (cf. Ps. 47:10);

4. Good, restoring hope to the poor (Job 5:16), and repairer of the breach (Isa 58:12)

5. laid in this tomb with an honest name.

6. Despite the splendour of his richness (Esth 5:11), the gold is as his dust.

7. There is nothing good for men (see Eccl 8:15) than to be exalted of heart ${ }^{8}$,

8. to bring knowledge of the fate you are running to.

Prose part:

9. The excellent, honoured Refael Hizqiya, may the memory of the righteous be a blessing,

10. from Forlì, rose to God on 11 Nisan 5352 (March 23, 1592). May his soul be bound up in the bundle of life.

Comment:

As we can see, the classic structure of the text of the epitaph is composed of two parts: the first is in poetry which, in the epitaphs of the late sixteenth century, the golden era of Baroque, until the eighteenth century, is in rhyme and rhythm, and constructs a eulogy of the deceased. The poetic part is an ottava rima where the lines 1, 3, 5 and 7 are decasyllabic composed of 5 iamb verses; lines 2 and 6 are hendecasyllables composed by 3 iambs, 1 anapaest and 1 iamb verses; line 4 is an dodecasyllabic verse, the central one adopting a different rhythm and is composed of 1 anapaest, 2 iambs, 1 anapaest and a trochee. So we have a wonderfully elaborate structure, with the composer making the most of the rhyme and rhythm, as well as of parallelism. There is a connection between lines $1=3=5=7$ which all end in -im, and $2=4=6=8$ all ending in -eș.

\section{The structure and various registers of the speaker in the epitaphs}

In the epitaphs, the deceased's virtues are often celebrated with words quoted from the Bible, but at the same time the poet invites the visitor to consider the vanity of the human condition, emphasizing the shortness of human life because of the fuga temporis, as is made evident by the inevitability of death,

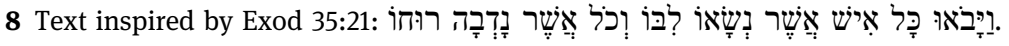




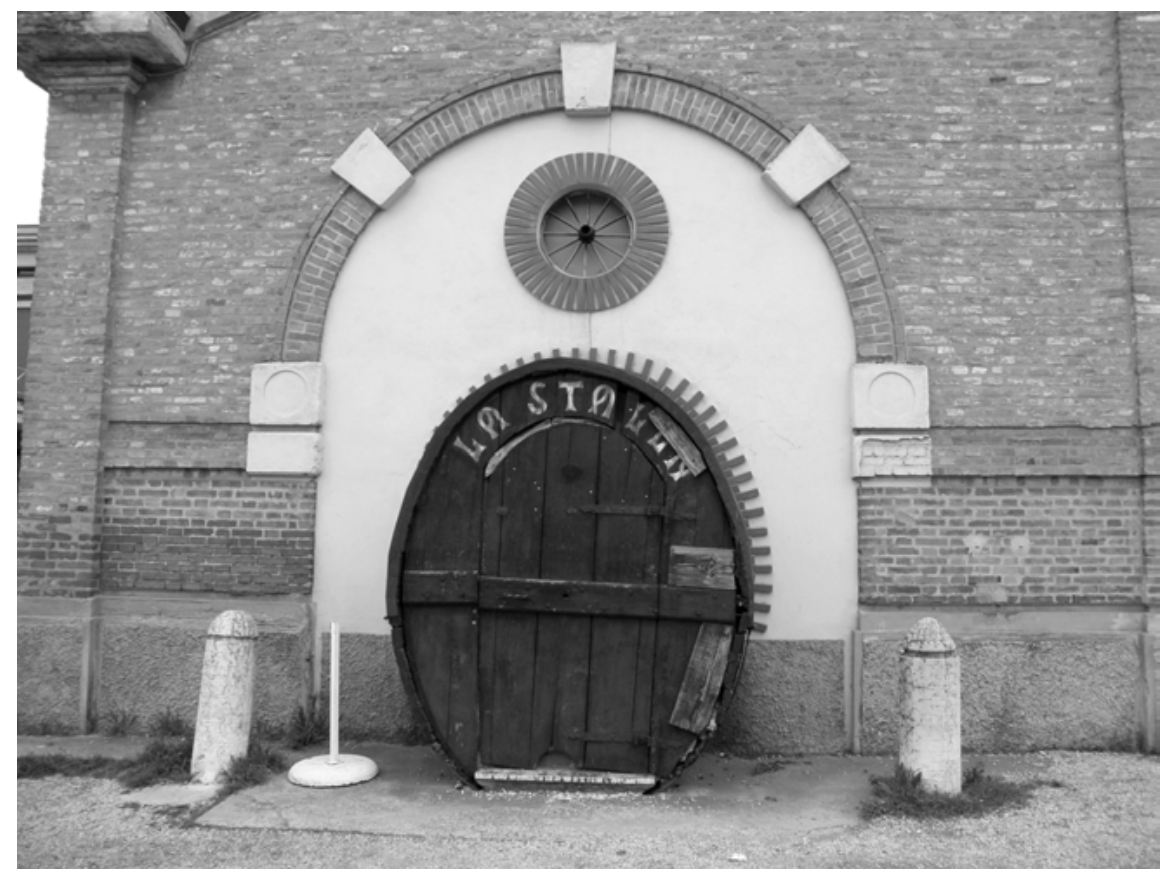

Fig. 5: The entrance to the former Pizzeria "La Stalla" in Cerese, not far from Mantua, with two cylindrical Jewish funerary pillars, reused as ornamental elements. On the right side, the one of Avraham Yedidya Basilea, brother of the Mantua kabbalist, Avi'ad Sar Shalom Basilea, who passed away in 1748, in July. On the left side, that of Avraham Hayyim Norsa, who died in 1783, both leading Rabbis in Mantua during the $18^{\text {th }}$ century. Despite my efforts to obtain permission to bring the funerary pillars to the Jewish community in Mantua, with the intention to putting them in a museum, together with other Mantua mașevot of the $16^{\text {th }}$ $18^{\text {th }}$ centuries, the two pillars remain, up to now, at the place where the picture was taken.

and invites visitors and passers-by to reflect on that, to spare a thought for the deceased, and to follow his moral example. The second part is in prose and gives general information about the deceased's name, his characteristics, often his main family relations, the date of death and sometimes also its causes. The order of these two parts is interchangeable and each part can be placed either at the beginning of the epitaph, or at its end. Who is speaking in the text of the epitaph? There are several possibilities: sometimes it is either the tombstone that speaks for itself, inviting the passer-by to reflect on the fugacity of life and to turn his mind to the dead and pray for him; but the speaker, in the literary representation, is occasionally the dead himself, asking the visitor to enjoy his life, to thank God for being still alive and to consider the vanity of events that make men rush through life, following in particular the religious reflections of Qohelet and Job, which are, not by chance, and 
together with Proverbs, the most quoted books in the epitaphs; a hidden voice sometimes speaks to the visitor, describing the situation of the dead in macabre terms such as 'consumed by worms' and as in a state of decomposition, in order to make an impression on the visitor and to encourage him to be attached in his present life to eternal and important values, and to everlasting things. Havel havalim ha-kol-havel of Eccl 1:2 is used as a refrain, to remind the living of the vanity of all existing things.

I discovered a most interesting epitaph in Cerese, near Mantua, where a cylindrical pillar, probably at the beginning of the Ottocento, was reused as an ornamental element at the entrance of the Pizzeria 'La Stalla' (Fig. 5). The dead, Avraham Hayyim Norsa, was a prominent rabbi in Mantua during the eighteenth century and had passed away on the eighth day of the month of Shevat in 5543, equivalent to $11^{\text {th }}$ January 1783 (Fig. 6). Here its text is presented, with an interpretation that improves on the one I published in my book on the Jewish cemeteries of Mantua9:

Hebrew text:

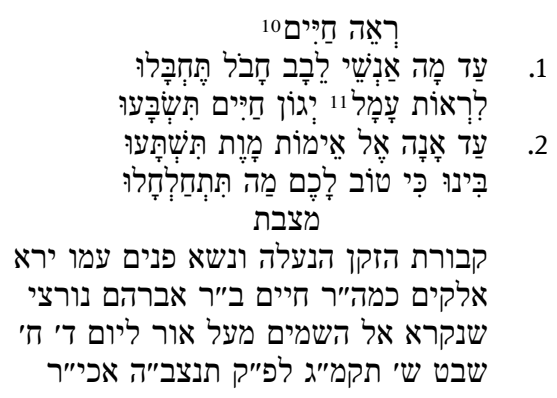

9 See Il 'giardino' degli ebrei: Cimiteri ebraici del Mantovano, quoted in n. 2 above, p. 148, epitaph no. 16; after a more precise examination of the epigraph, which is still located in Cerese near Mantua, in front of the former pizzeria 'La Stalla', I achieved the improved reading yegon instead of the previous we-gan.

10 Eccl 9:9.

11 Compare. Eccl 1:3: מה יתרון לאדם בכל עמלו שיעמל תחת השמש. 


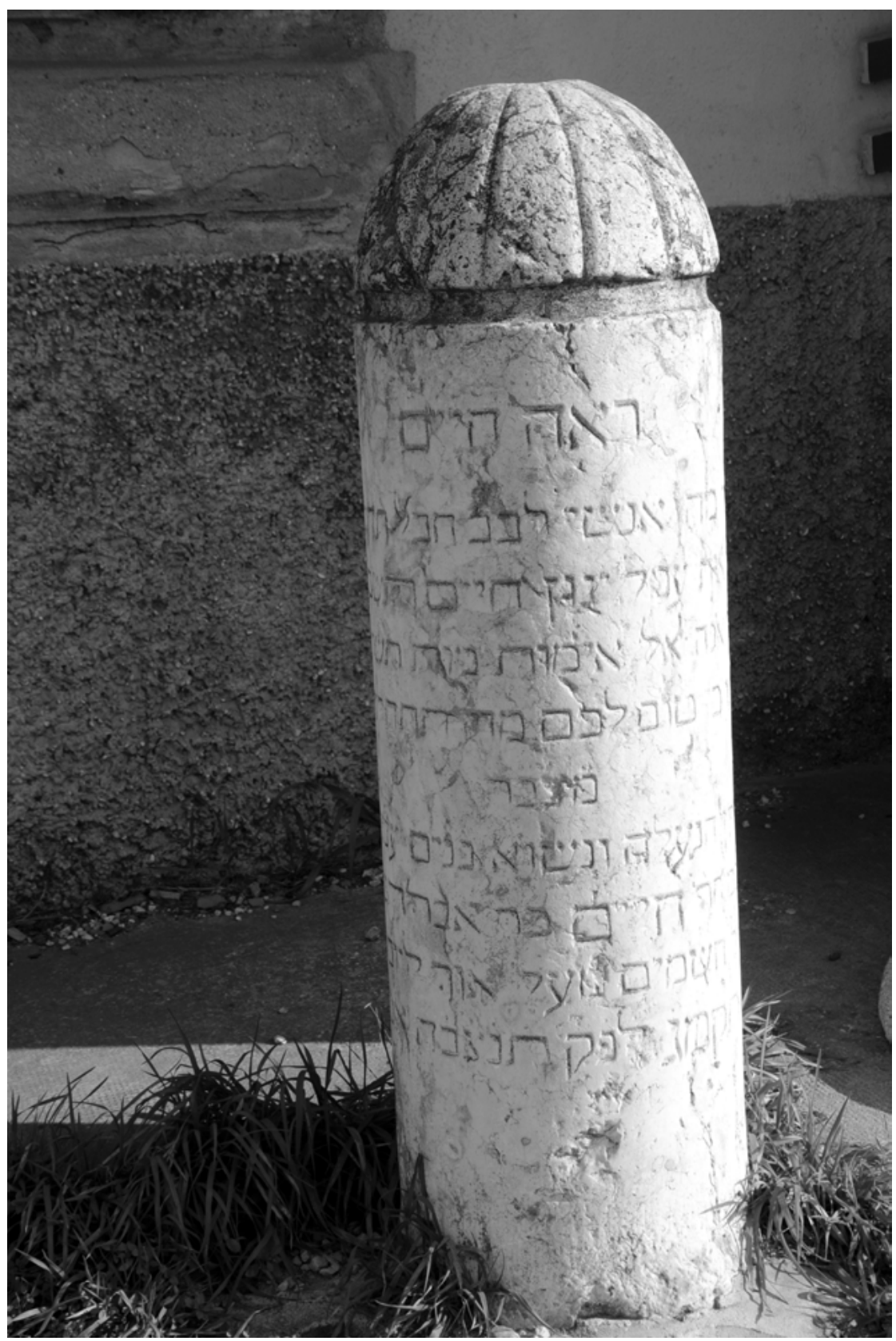

Fig. 6: The cylindrical pillar, engraved with the epitaph of Avraham Hayyim Norsa, a prominent rabbi in Mantua during the $18^{\text {th }}$ century, who passed away on 8 Shevat in 5543 (11 January 1783). See fig. 5 above. 
Opening biblical motto:

Enjoy life (Eccl 9:9).

English version

Poetic part:

How long, o men of understanding, will you devote yourselves to the struggle / taking your fill of painful desires and anguished life / how long will you fear the terrors of death / why be afraid of what is good for you

Prose part:

Sepulchral stone / of the distinguished elder, revered by his people and fearing / God, R. Hayyim, the son of Avraham Norsa, / summoned to heaven above during the night of Wednesday 8 / Shevat in the year 5543 (= 1783) of the minor computation. May his soul be bound up in the bundle of life. Amen and so be it.

Comment:

This epitaph is addressed to the passer-by, or the visitor, who sees the memorial stone at the cemetery. The sense of this epitaph, characterized by a sympathetic vein of Qoheletic cynicism, can be succinctly summarized as an invitation not to be afraid of death but to contrast this life with the eternal life. The poetic part is a quatrain that follows the rhythmical scheme A B B A (known as enclosed rhyme) with an ending in - $l u$ and $B$ in - $u$. As for the metrical structure, the stanza is composed as follows: line 1 is dodecasyllables ( 3 iambs, 1 trochee, 2 iambs); line 2 is of fourteen syllables (all 7 iambs); line 3 is hendecasyllabic ( 3 iambs, 1 trochee, 1 anapaest); and finally line 4 is hendecasyllabic as well ( 3 iambs, 1 anapaest, 1 iamb). As far the rhyme is concerned, the ending vowel is always identical through the quatrain. Each line of the poem has eleven syllables, stressed milra', all with long vowels. The word 'life', in Hebrew hayyim, is also the name of the deceased, and the composer of the epitaph is making a play on the double meaning of the term. In the literary fiction, the poet invites the passersby to 'consider hayyim', citing Eccl 9:9, which opens as the motto of the first poetic part.

\section{The integration of data found in the epitaphs with other sources recording a death}

I wish to offer here an interesting example of the fruitful integration of historical information contained in the epitaph of a leading rabbi of the Jewish community in Lugo with the important information given in the text dealing with his death in the above-mentioned manuscript of New York containing the 


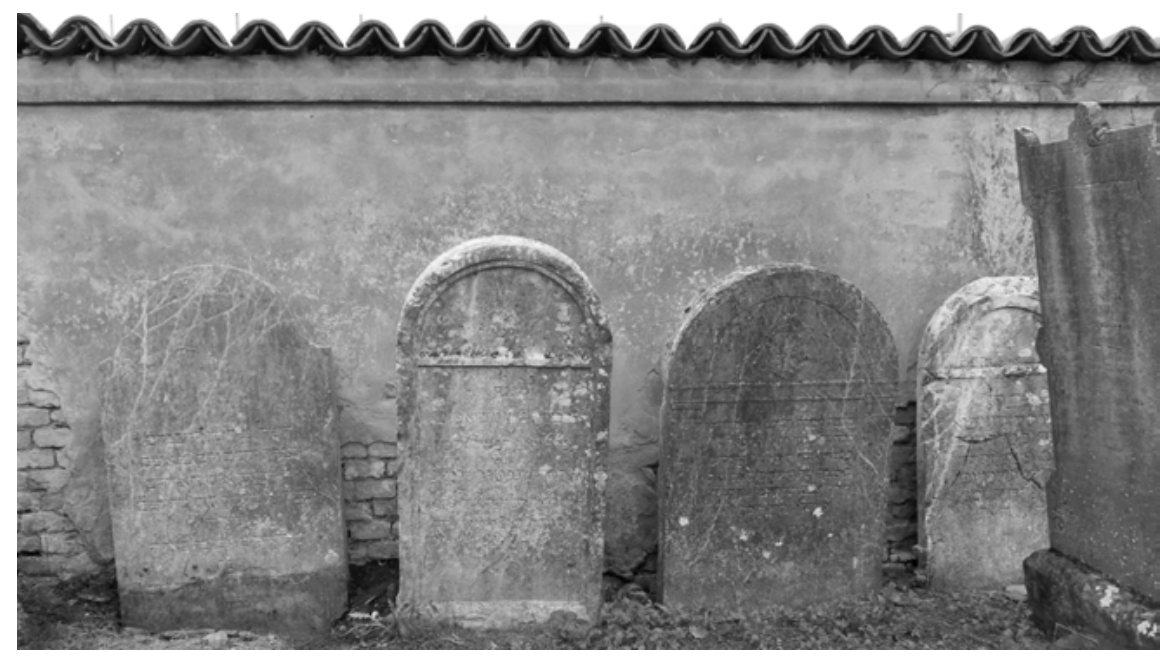

Fig. 7: Jewish cemetery in Lugo with, on the left, the tombstone of Rabbi Shelomo David Del Vecchio (me-ha-Zeqenim), son of Moshe, who lived between the second half of the $18^{\text {th }}$ and the beginning of the $19^{\text {th }}$ century and passed away on 10 Adar 5583 (February 1823). He was one of a dozen Italian Rabbis who attended the second session of the Grand Sanhedrin convened by Napoleon Bonaparte in 1807 in Paris.

Pinqas Ha-Niftarim of the Jews of Lugo. I am speaking of Rabbi Shelomo David Del Vecchio (me-ha-zeqenim), son of Moshe, who lived between the second half of the eighteenth and the first quarter of the nineteenth century and passedaway on 10 Adar 5583, i.e. 21 February, 1823. He was one of the leading rabbi of Lugo, the last member of his family, which was one of the most ancient among the Jewish families of Lugo. This small city developed great importance for the local presence of Jews after an ecclesiastical ordinance, ordering a concentration of all the Jewish population of the new Legazione pontificia after the Devoluzione of Ferrara, from the Estense Duchy, to Papal territory. In fact, Lugo passed from the Duchy of the house of Este to the Church's State, where many of the rights, previously enjoyed by the Jews, were cut back. Pope Urbanus VIII in 1638 ordered the Jews to concentrate and relocate in only the three cities of Lugo, Cento and Ferrara. For this reason, Lugo's small Jewish community increased substantially and became one of the most important centres of Jewish presence and culture in north Italy, starting from the seventeenth century and lasting for about two hundred years. According to a population census carried out in Lugo in 1638, the Jews represented 10 per cent of the whole population. Rabbi Shelomo David, the last of the great rabbis of this community, was a theologian, philosopher and poet. At eighteen, he became the spiritual leader of the community of Lugo and he was the head of the local rabbinical academy. When Napoleon Bonaparte summoned 


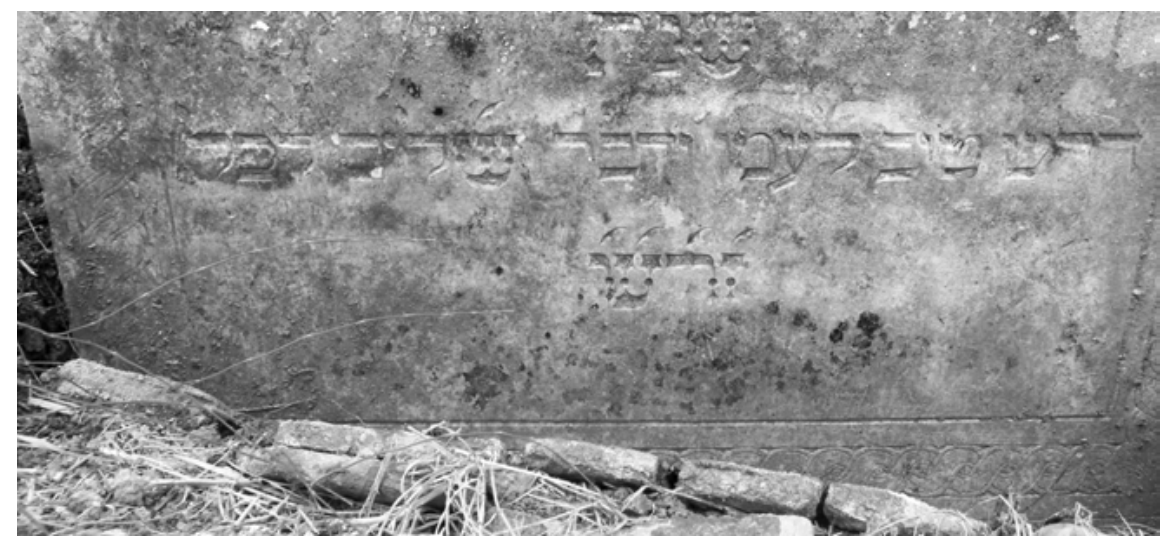

Fig. 8: The last part of the epitaph of Rabbi Shelomo David Del Vecchio, indicating the year of his death, using the last verse of the book of Esther: שנת דרש טוב לעמו ודבר שלום לכל ז' זרنוֹ letters to be calculated are highlighted by a stroke.

the second session of the Grand Sanhedrin in 1807, in Paris, he was one of the participants. In 1815, he was sent to Rome to negotiate less severe conditions for the Jews after the restoration of pontifical rule. He owned a library of great value. Let us now see how much valuable information can be found in the record of his death contained in manuscript no. 3960 of Jewish Theological Seminary in New York, in addition to what we read in his epitaph. This is the text engraved on his tombstone, kept in the Jewish cemetery of Lugo (Figs. 7 and 8):

Hebrew text:

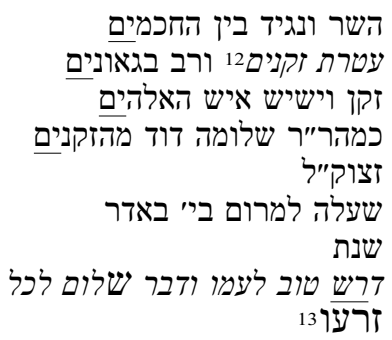

We see that the above text is fairly concise and succinct, when compared with the information gathered from of the New York manuscript's record of his death, which contains a fine piyyut in rhyme and rhythm, longer than that of the epitaph, and a lengthy report of the funeral ceremony. (Fig. 9): 


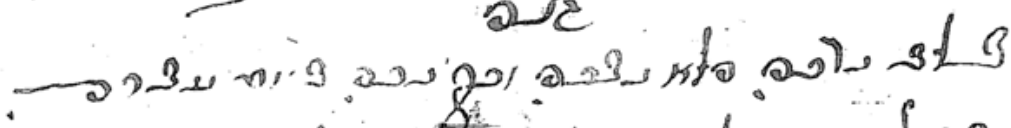

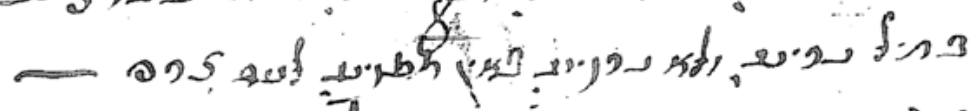

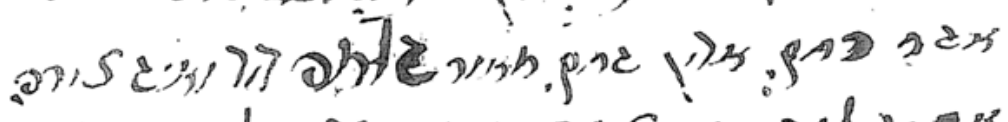

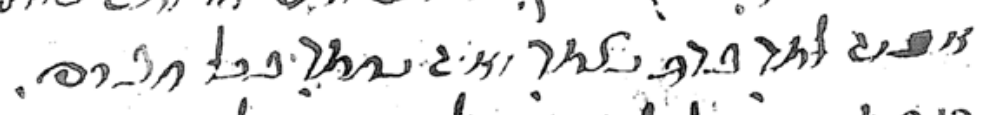

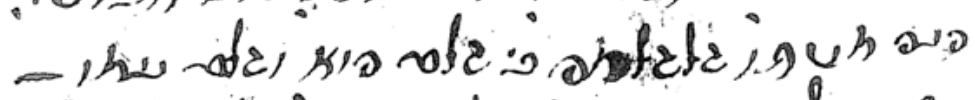

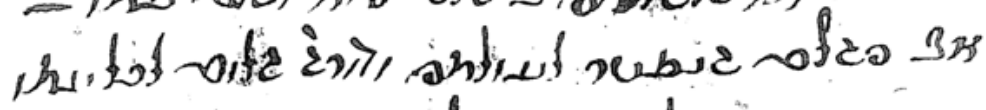

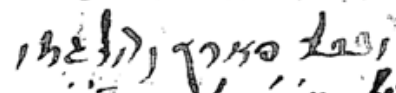

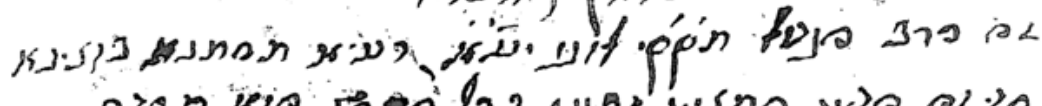

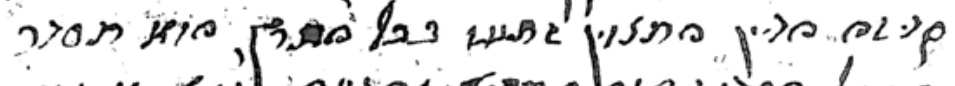

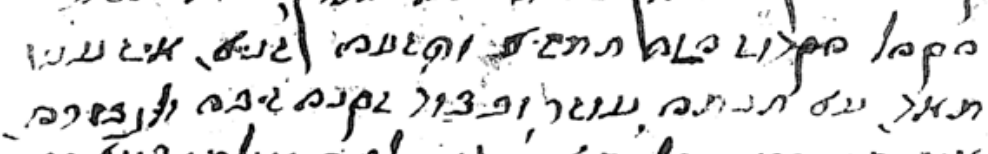

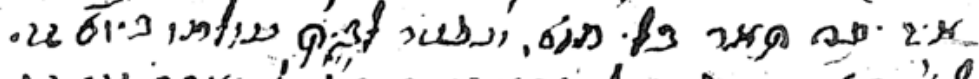

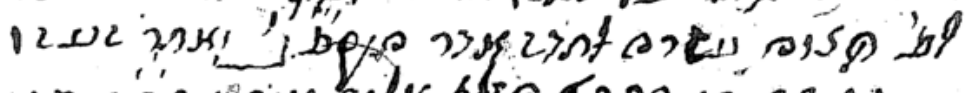

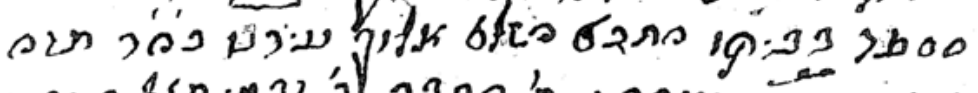

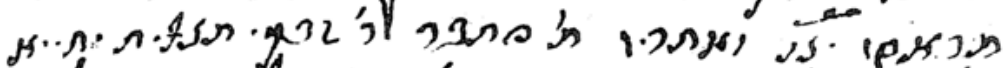

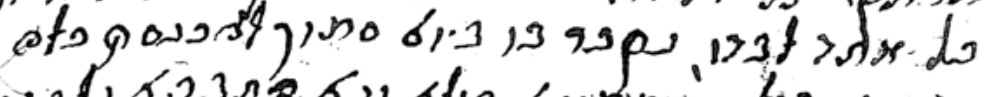

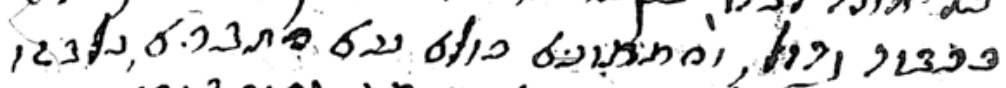

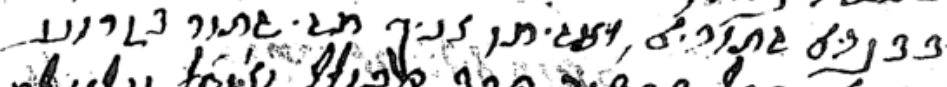

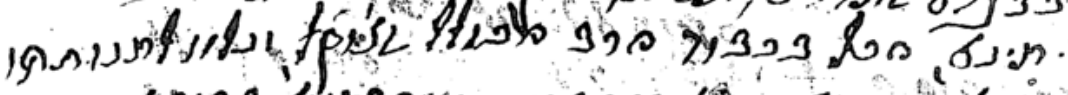
6 -

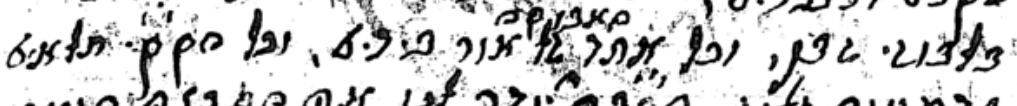

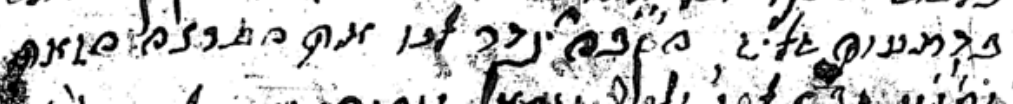

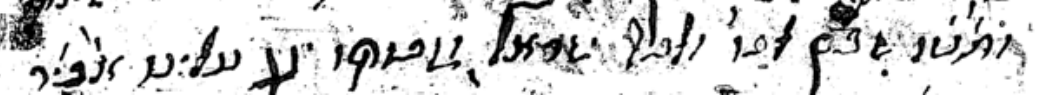

Fig. 9: F. 81r of the manuscript recording the death of Rabbi Shelomo David del Vecchio; see fig. 1 above. 
Opening biblical motto:

עטרת תפארת שיבה,14 ואם בגבורות שמונים

שנהת 15

Hebrew text:

Poetic part:

1.

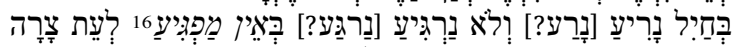
2.

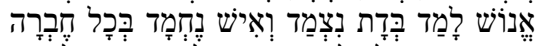

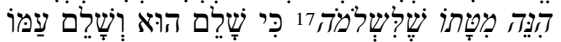

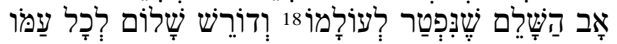

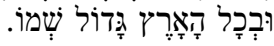

Prose part:

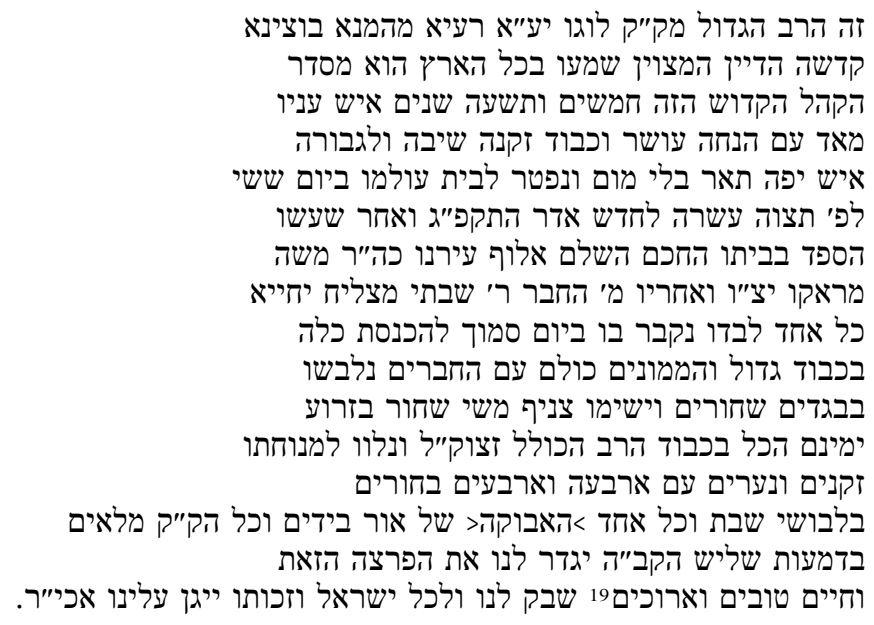

The poem is in the Spanish style of sixteen syllables, structured as $4 \times 4$, with some deviation in lines 5-6 and considerable variation in the last line.

14 Prov 16:31.

15 Ps 90:10.

16 Compare Isa 59:16.

17 Cant 3:7.

18 The manuscript has לעולמה instead of לעולמו which seems to be wrong, possibly influenced by the word שלשלמה she-li-Shelomo in which the final -o cited from Cant 3:7 in the name Shelomo ends in $-h$.

19 The manuscript has the abbreviation: וחט"ו. 
English version:

Opening biblical motto :

The hoary head is a crown of glory (Prov 16:31), He who has the strength arrives at eighty (Ps 90:10)

\section{Poetic part:}

With a broken heart we cry and smite our palms on the day of anger, / and powerfully we cry, we do not rest, because there is no one who can intercede in time of trouble, / in which [time of trouble] the Lord has turned away, he has extinguished the light of Shelomo David, who was a worthy and learned man, attached to religion, a man most pleasant among the whole brotherhood. / This is the bier of Shelomo, for he was perfect, and peace was with him - he was the perfect father and he departed for the eternal life, he sought peace for all its people (see Esth 10: 3), / and his name was great over all the earth.

\section{Prose part:}

He was the great rabbi of the holy community of Lugo - may the Most High protect, Amen - the faithful shepherd, holy light, incomparable judge, known throughout the world. He led this holy community for fifty-nine years. He was a very humble man as well as blessed with satisfaction, wealth, honour, old age, gray hair and seniority. He was a handsome man, impeccable, and he departed on the sixth day (Friday) of the parasha Teșawweh, on 10 Adar 5583. After eulogies had been separately delivered at his home by the wise leader of our city, the respected Rabbi Moshe Morocco - may God, his Rock, protect and maintain him - and, after him, by our teacher and colleague Rabbi Shabbetai Mașliah Yahya, he was then buried on that same day with great honour just before the arrival of the bride (the Sabbath).

All the officer bearers and all the members (of the burial society) were clothed in black and wore a black silk arm-band on their right arms. They did this in honour of the most learned rabbi - may the memory of the righteous and the holy be a blessing. The old men and, with them, the boys, and forty-four young men dressed in Sabbath clothes, with each of them holding a candle, then accompanied him to his grave. All members of the holy community shed abundant tears [Ps 80:6]. May the Holy One, blessed be He, repair this breach for us. And he left with us and with all Israel (the memory of) a good and long life. May his merit protect us. Amen; may God's will be done.

\section{Comment:}

The poetic part in the manuscript places on the same line what I have

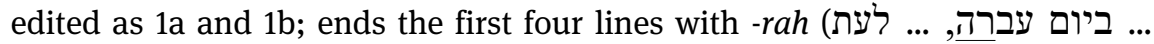

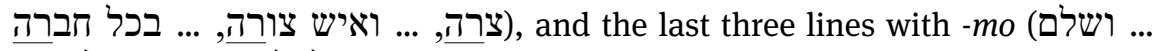

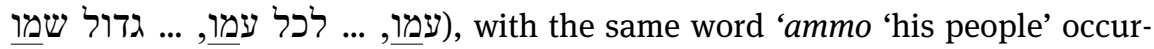
ring twice, and shemo 'his name' in the last line. It is interesting to note that the poem written in the manuscript report of his death is longer, richer in detail, and rather different from that engraved on the tombstone of Rav Del 
Vecchio, which is much shorter and basic. Both versions, however, regard as a crucial a citation, with some variations, of the last verse of the book of Esther: doresh shalom le-khol 'ammo, 'he sought peace for all his people', for the original doresh tov le-'ammo we-dover shalom le-khol zar'o. The emphasis is of course here being placed on his people: the rabbi had been a good shepherd for the community of Lugo that he served for almost sixty years. His cultural standing and the public role he played on the occasion of the second session of the Grand Sanhedrin, in which he had been invited to participate together with a dozen other leading rabbis as a representative of the Jewish communities of the northern Italy under the Napoleonic empire, is pointed out and celebrated in both the epitaph and in the record of his of death, so that his role can be compared there with that of Mordechai in the Bible.

From the manuscript record of his death we glean new information (some of it perhaps somewhat hyperbolic) not included in the epitaph, namely, that he served as rabbi the Jewish community of Lugo for fifty-nine years, that he was a very humble man, a faithful and impeccable shepherd, a holy light, an incomparable judge known throughout the world, blessed with many distinguished attributes. There is in this source even a somewhat unexpected note in which the scribe-poet tell us that he was a handsome man. Two rabbis of the community gave funeral orations, and he was buried with great honour at the auspicious time of Friday afternoon. This description of the whole funerary procession is most impressive and charming.

\section{Palaeography and style of the Jewish epitaphs on burial stones}

Like any manuscript or other text, funerary inscriptions must also be studied as palaeographic documents taking due account of the style and shape of their letters. We have to treat the Hebrew sepulchral inscriptions of Italy with the same reasoning that we use for Italian Hebrew manuscripts. While the Hebrew manuscripts, epitaphs and inscriptions found in the Ashkenazi area are written exclusively in Ashkenazi style, and those found in Sefardi countries are only in Sefardi style, the contrary situation applies in Italy, where there is evidence not only of the Italian style but also of the other two, both Ashkenazi (Fig. 10) and Sefardi (Fig. 11). In other words, we observe in the texts of funerary inscriptions the same phenomenon encountered in Hebrew manuscripts of Italy: they are written in all three main types of script used in the Western world, ie Italian (Fig. 12), Sefardi (Fig. 13) and Ashkenazi (Fig. 14). This multicultural nature of Italy is due to its central geographical position in the Mediterranean basin, and also has cultural and historical reasons. Italy, in fact, 


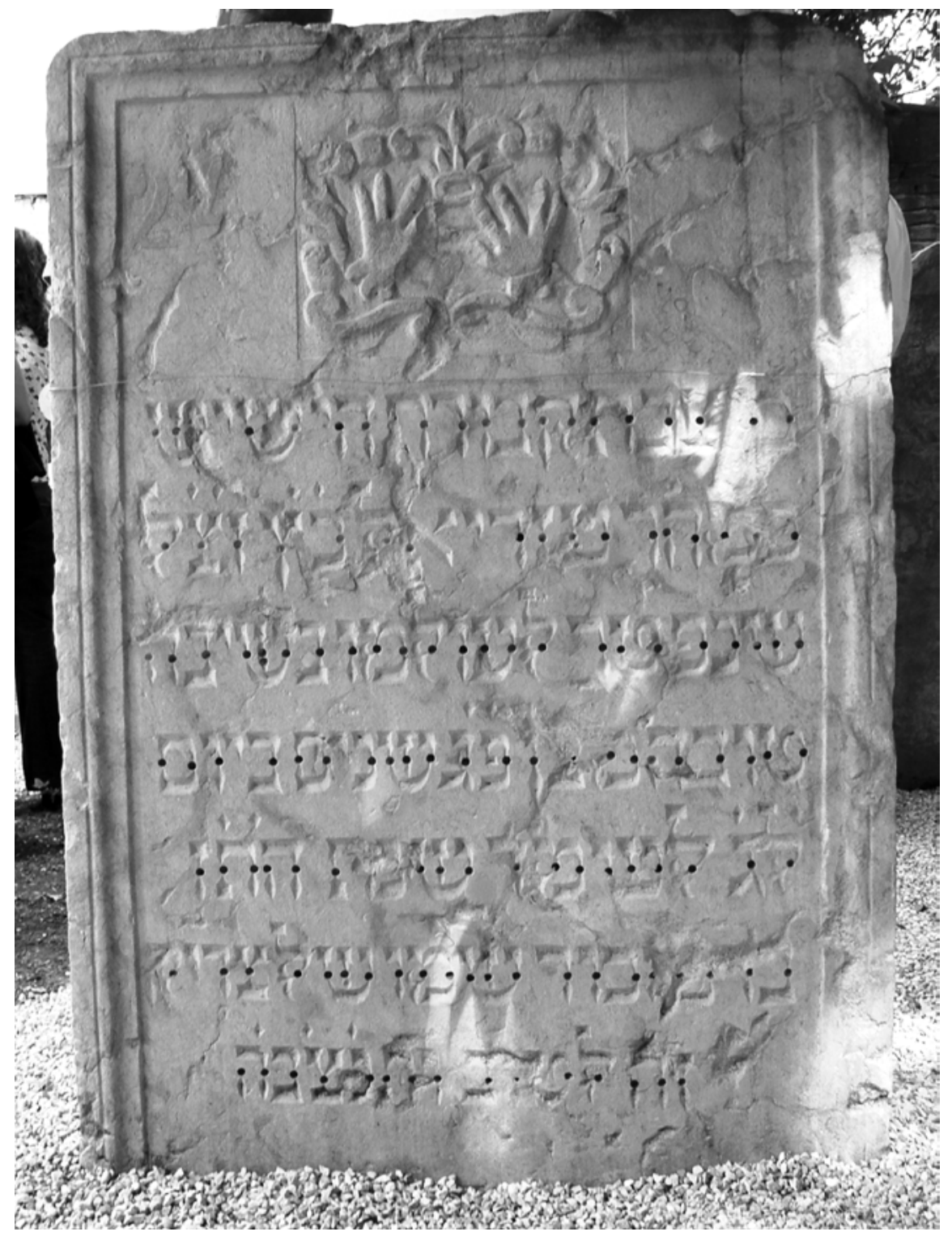

Fig. 10: An example of Ashkenazi-style engraved letters in the mașeva of Azriel Kohen Sedeq, who died at the age of 83 on Lag ba-'omer 5407 (1647 CE), at the Jewish cemetery of Padua. 


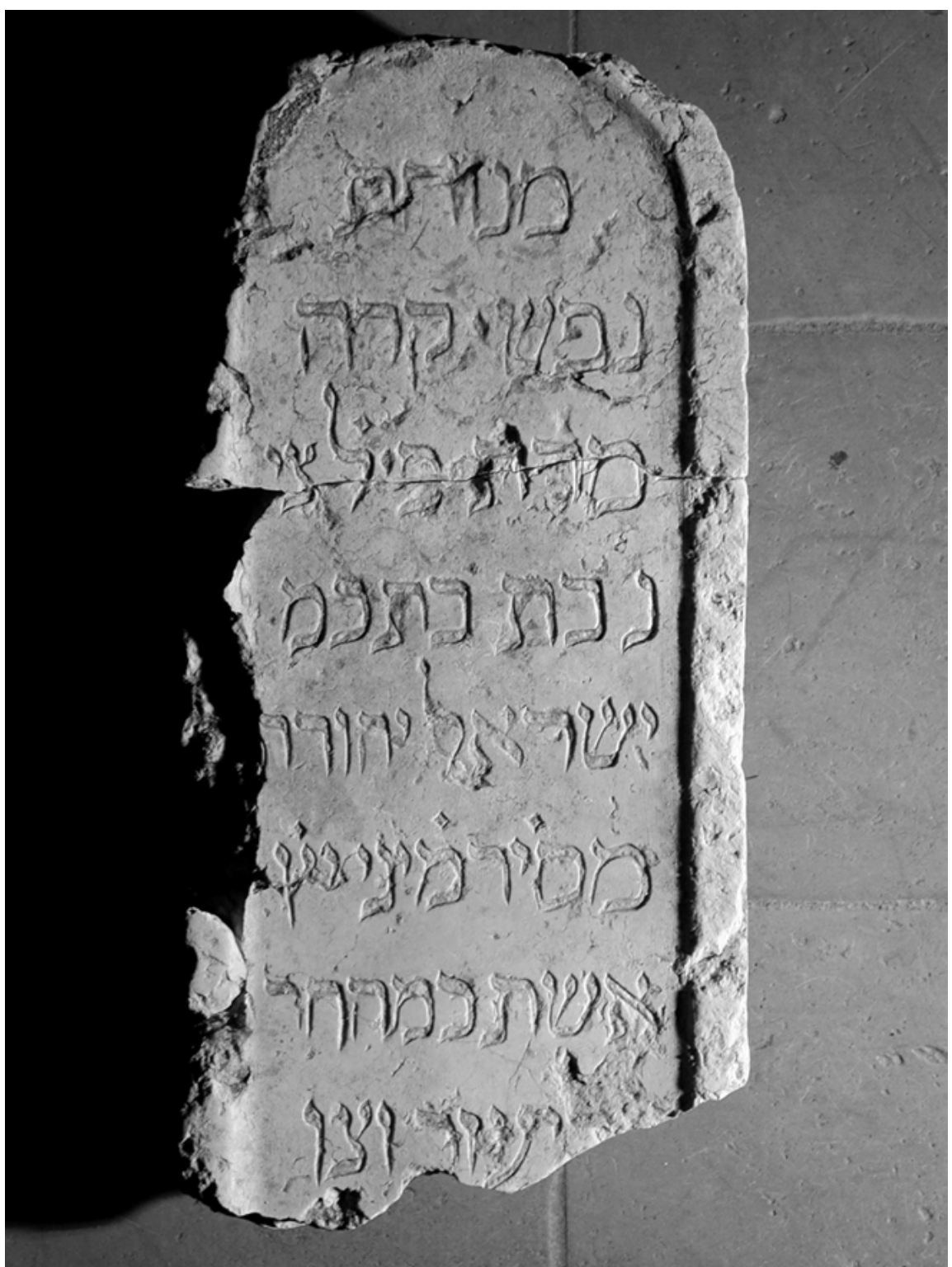

Fig. 11: Examples of Sefardi letters in the mașeva of Mrs Felice, the daughter of Yisrael Yehuda from Sermene (ancient name of Sermide in the Mantovano) and spouse of R. Eli'ezer. No clearly indicated date. It is unclear whether the points highlighting the lamed in the proper names Felice and Sermene, and perhaps the letter șade in the eulogy y"ș, indicate the figure representing the year of death 5330 (=1460 CE or without the value of lamed in Felice, $5300=1430 \mathrm{CE}$ ). More probable is that the total numerical value of the name Sermene yields the date $5430 / 5400$ (=1670/1630 CE). 


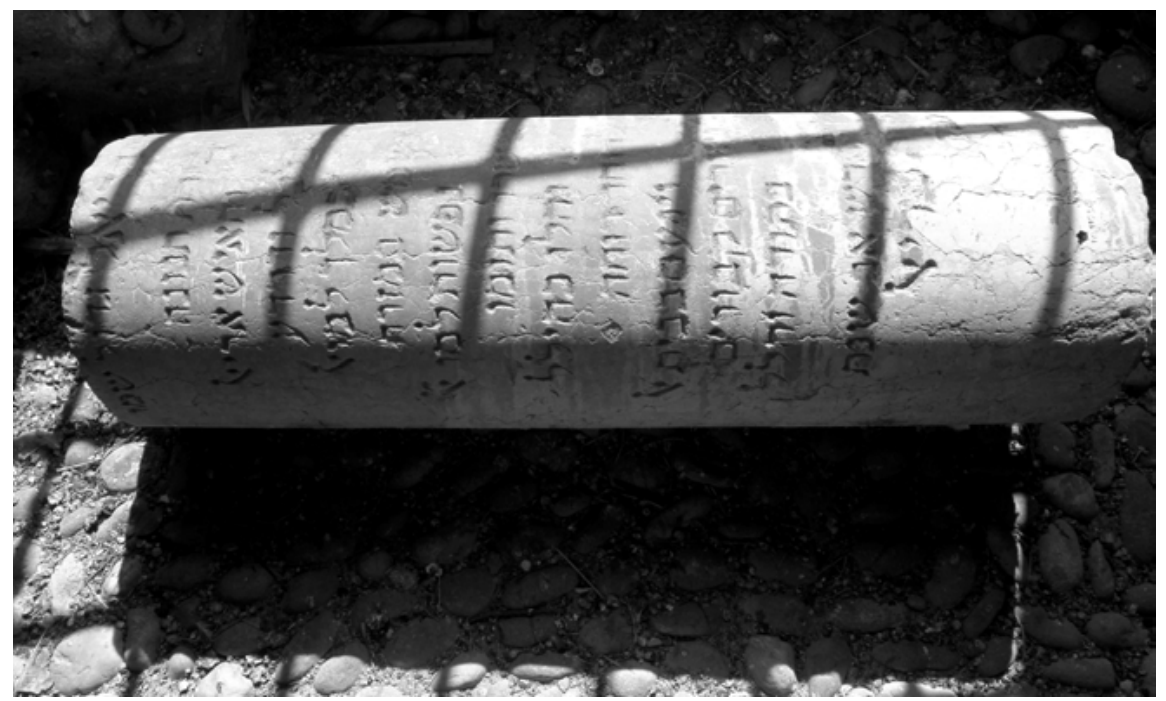

Fig. 12: Examples of Italian letters in the mașeva of R. Yehuda (Leone) ben Eli'ezer Briel (1643-1722), disciple of Moshe Zacuto and kabbalist, as his master.

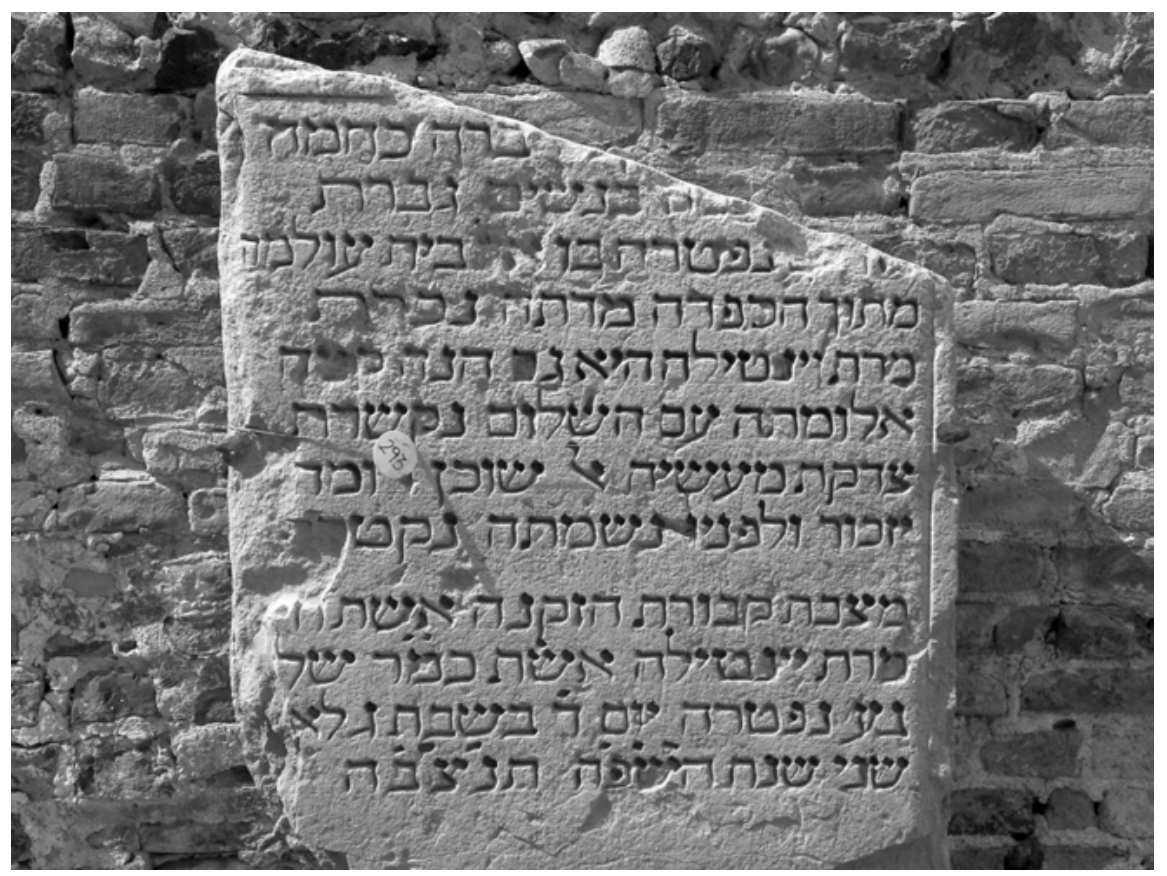

Fig. 13: Another example of a Sefardi script with Italian influence in the tombstone of Gentile the wife of Shelo[mo], who died on 3 Adar II in the year 5385 (1625 CE), preserved in the Jewish cemetery of Padua. 


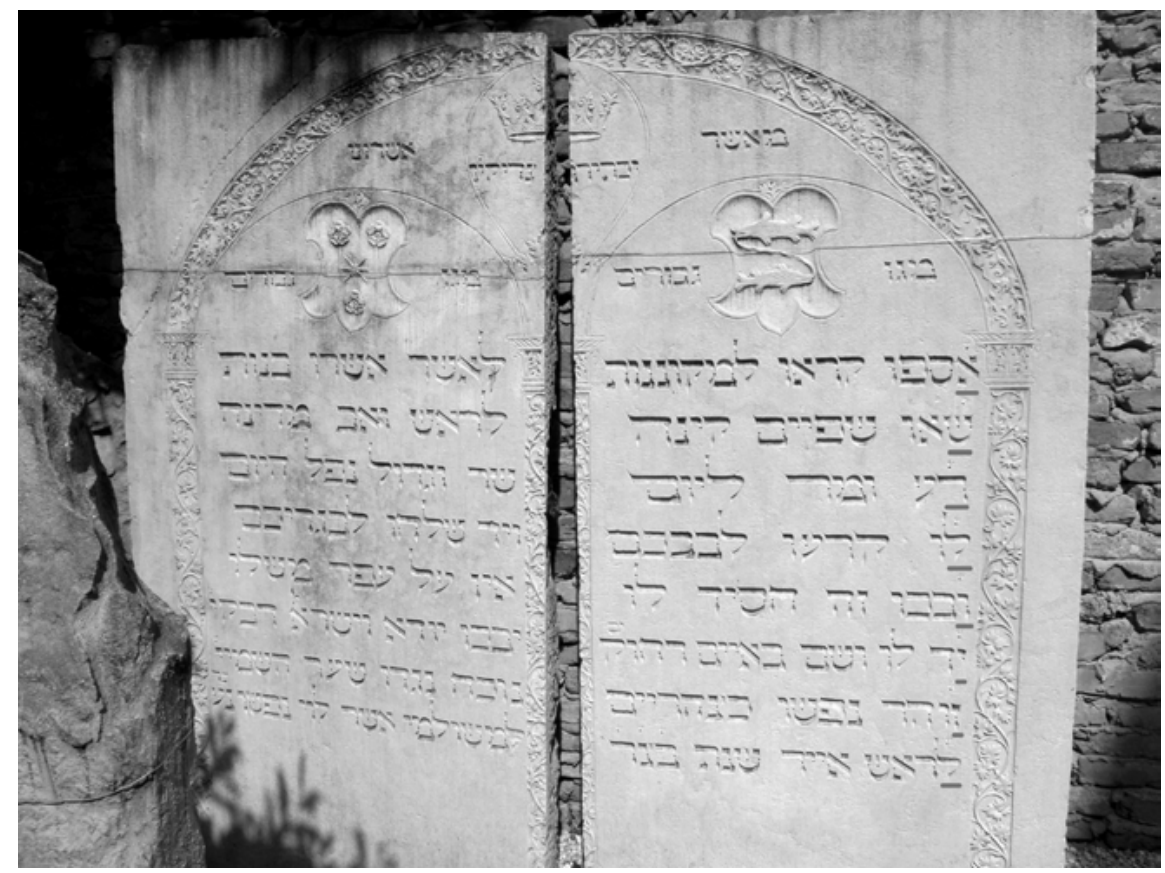

Fig. 14: Beautiful example of Ashkenazi letters in gem style (stile gemmato), used to engrave the epitaph of the "master and father of the town" (rosh we-av medina) Asher Levi, who died on 1 lyyar in the year 5292 (1532 CE), at the Jewish cemetery at Padua. The stone has been cut into two, probably for re-use. In this text we can detect two rhetoric and scribal devices. The name of the deceased and the eulogy z"l can be read as an acrostic of the first letters of the initial eight lines. Moreover, in the sixth line at the end of the right half of the stone, the sculptor has, for metrical reasons, written -im of the word rehoqim separately in the line spacing above; see the next figure below.

saw the immigration of many Jews from Spain, France and Germany, who had come for various reasons. They had been expelled from their homelands, they were using Italy as a transit point on their way to the Middle East, or they were attracted by Italy's culture in the Renaissance period and in modern time. This is documented by the abundance of Jewish epitaphs engraved in Ashkenazi style in the Italian Jewish cemeteries of the northern regions. Actually, following expulsions from their countries, many Ashkenazi Jews immigrated into northern and central Italy. Likewise, the presence of many funerary inscriptions sculpted in Sefardi characters, testifies to the expulsion of Jews from the Iberian peninsula. Their arrival enriched the Italian communities, and brought with it their Sefardi writing style, as used on their the epitaphs. The parallel situation between manuscripts and epitaphs, as just described, is attested in the major and large Jewish communities of northern and central 


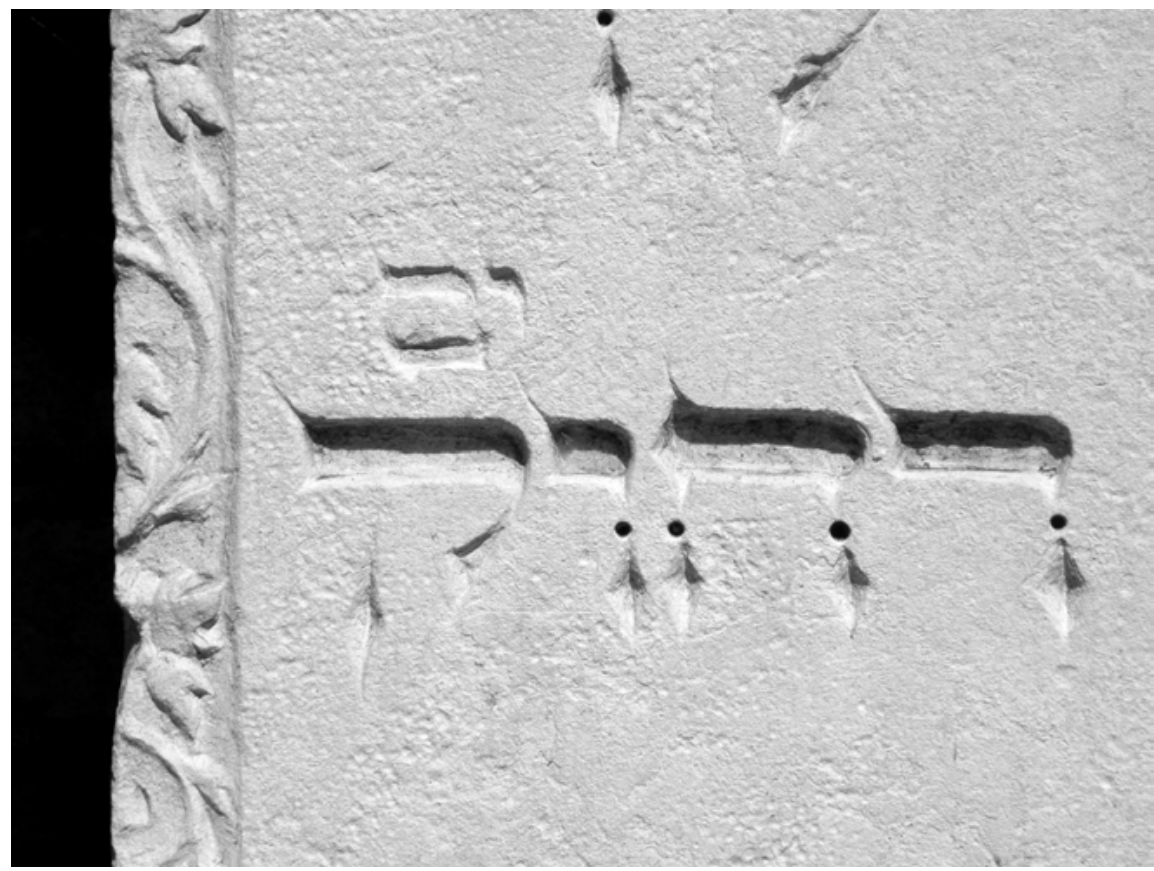

Fig. 15: Detail of the word of the word rehoqim with -im detached and written in the spacing above, in the epitaph of Asher Levi, who died in 1532, as found in the Jewish cemetery of Padua; see previous figure.

Italy, such as Mantua, Venice, Ferrara, Rome and various others. A curious device is the separation of two parts of a word for metrical reasons, as we can see in some tombstones, and another characteristic, as also found in manuscripts, is the writing of a word in small letters, upwards from the line, for reasons of physical justification (Fig. 15).

\section{Evolution, language and style of the Italian Jewish epitaphs}

Obviously, the style of Hebrew epitaphs in Italy was influenced by the culture of the ongoing centuries. The oldest tombstones, especially those of the sixteenth century, display the art and beauty of the Renaissance, are written in a beautiful calligraphy, embellished by the engraving of letters in a way similar to gem (stile gemmato) and with fine serifs, similar to the crowns used on the text of a Sefer Torah (Figs. 16, 17 and 18). Of course, such impressive monuments 


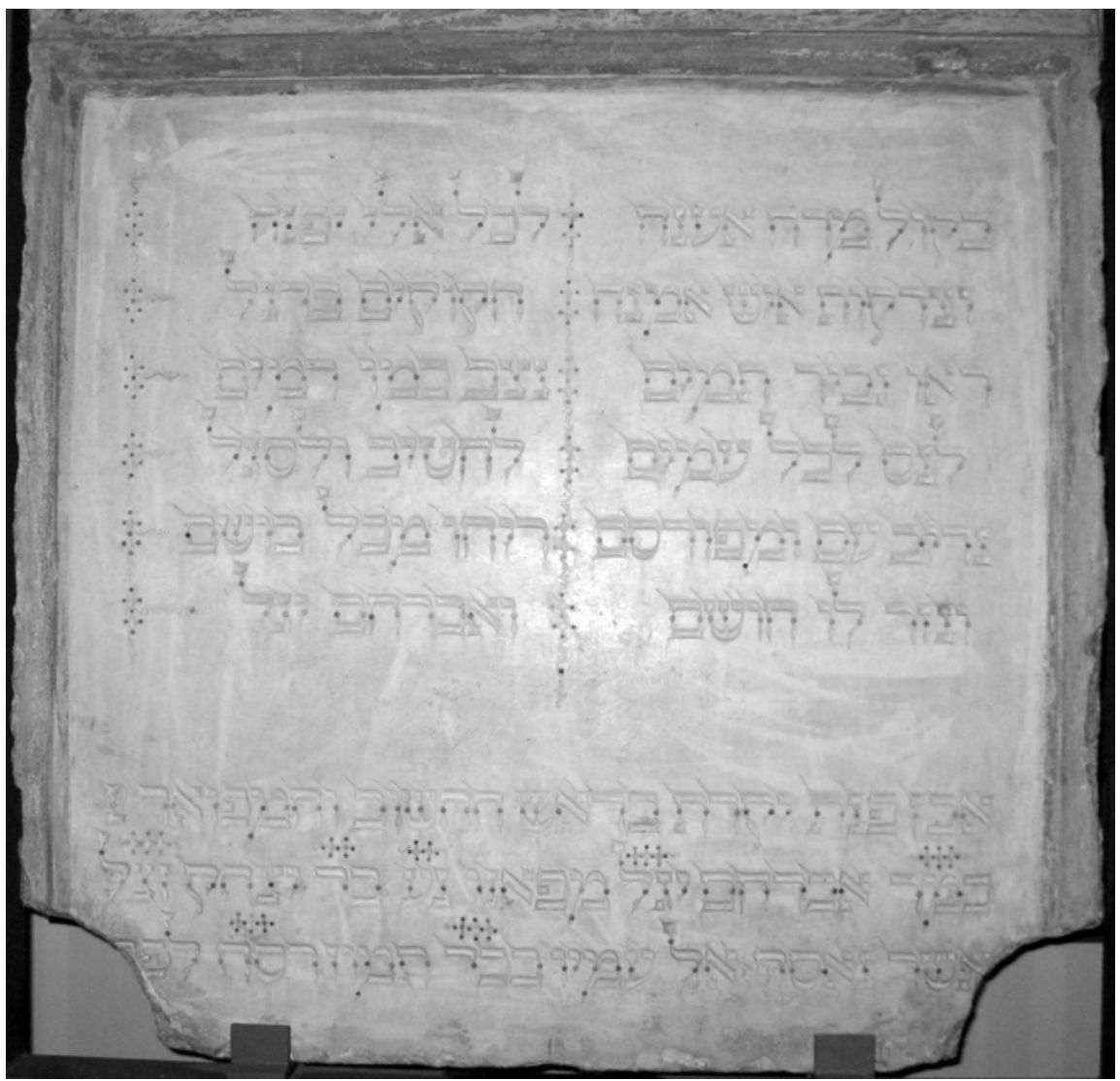

Fig. 16: A wonderful example of letters sculpted in Ashkenazi stile gemmato at the beginning of the $16^{\text {th }}$ century in the tombstone of the Bolognese banker, Avraham Yagel from Fano, who died on 24 Tammuz 5268 (1508 CE). The tombstone is kept in the Medieval Museum of Bologna.

were primarily reserved for the rich and for leading personalities, because their construction was a highly expensive exercise. There are also many examples of beautiful texts engraved in Sefardi letters, with the round shapes of their characters. As for as the language of the epitaphs is concerned, Hebrew was the only one used until the nineteenth century, when a short summary of the Hebrew starts to be written in Italian. Slowly, the Italian part prevails over that of the Hebrew, until the sacred language completely disappears. This cultural phenomenon reflects the progressive loss of the Hebrew language by many Jews. This process culminates in the second half of the nineteenth and the first half of the twentieth century with the almost total abandonment of Hebrew in 


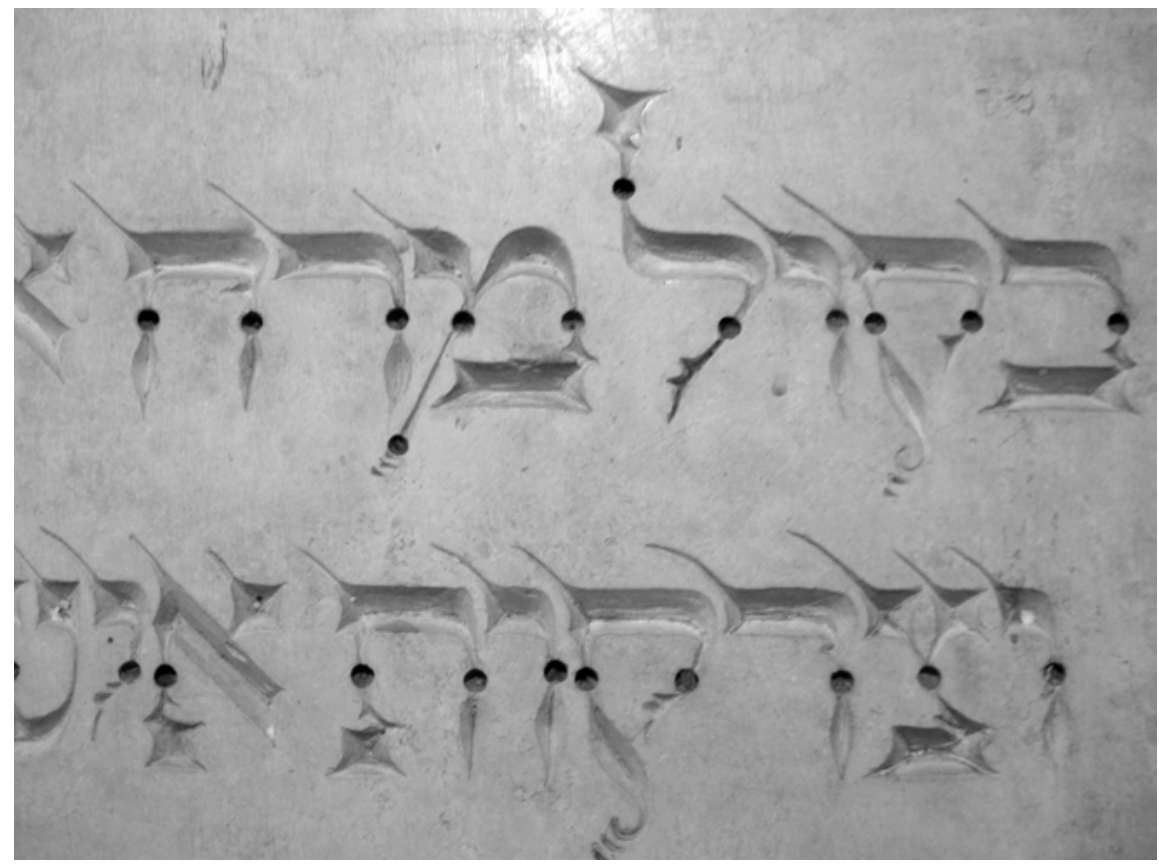

Fig. 17: A detail of some letters with wonderful serifs and small circles in sculpted Ashkenazi stile gemmato at the beginning of the $16^{\text {th }}$ century in the tombstone of the Bolognese banker Avraham Yagel from Fano, who died in 1508. We see the gem-shaped upper and lower part of the letters, especially șade and alef and the curled lower part of the qof; the tombstone is kept in the Medieval Museum of Bologna.

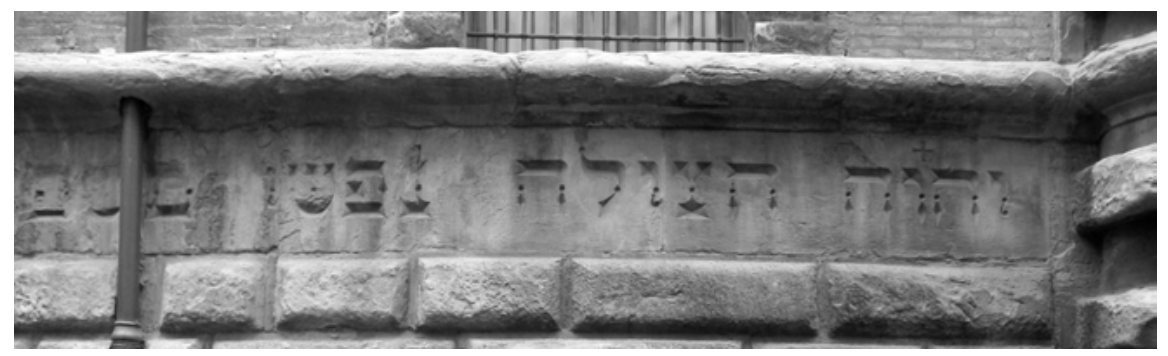

Fig. 18: A verse from Psalms 120:2 sculpted in Ashkenazi gem-shaped style on the wall of Palazzo Bocchi in Bologna, together with Latin and Greek verses, built by the humanist Achille Bocchi (1488-1562). The building, designed by Jacopo Barozzi da Vignola, was inaugurated in 1546 and became the seat of the Hermathena Academy that he founded years before, and the name of which is a fusion of Hermes and Athena. 


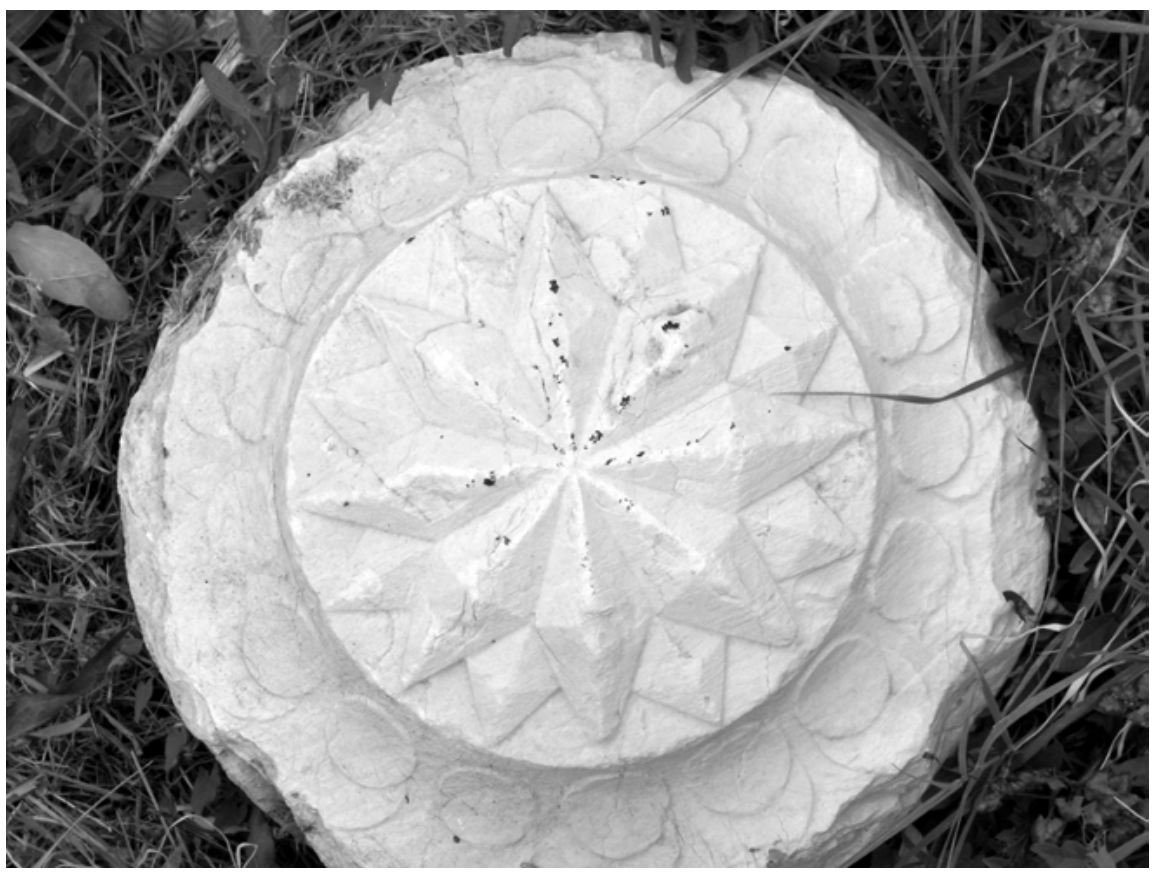

Fig. 19: The top of a cylindrical tombstone in Istria stone from the Jewish cemetery of Cardeto in Ancona, with a figure of a sixteen-petal-flower or of a sun with sixteen rays. This image is very frequently used in the tombstones of the Marches, but it is unclear whether it is purely ornamental or whether it has some other, unknown meaning.

favour of Italian. Only a few words of Hebrew remains, such as shalom, or the abbreviation of the eulogy tehi nafsho/-a șerura bi-șeror ha-hayyim.

This unfortunate phenomenon is connected with the loss of Jewish culture by the Italian communities after the proclamation of Italy as a unified state in 1861, and reflects the climate of secularization and of modernism that characterized that century. After the emancipation, and after leaving the ghettos, the Jews wanted finally to be citizens with full civil rights like everyone else and they were attracted by modern life and science, often abandoning their culture and religion, to become assimilated into the external world. A particular problem that I wish to point out is the transition of mașevot from the classical marble slab to that of the cylindrical pillar that occurred at the end of the sixteenth century in some Italian regions, especially in the Marches. In my research on the Jewish cemeteries of the Marches, and especially on the largest one of Ancona, I was surprised to see that the shape of the tombstones in the last decade of the sixteenth century passes quickly to the cylindrical (Fig. 19), a new form which, at the end of sixteenth and in the seventeenth century 
accounted for $95 \%$ of the total. The Marches tombstones, as already indicated, are very well preserved because they were made using the hard Istria stone (pietra d'Istria), transferred by ship from the Istria peninsula to the centres on the Marches coast of the Adriatic Sea. This is a very hard stone, resistant to temperature changes and extremely durable. But how do we explain this sudden change in the community of the Marches? At the moment I can only speculate. The cylindrical shape is typically used by the Sefardi Jews, who probably borrowed it from North Africa. We know that many Sefardi Jews who were expelled in 1492 went to Italy and to the Levant region of Turkey. The style was probably imported by the Sefardim who came to Ancona and other towns of the Marches, and its adoption was then strengthened by the trade relations between the great commercial port of Ancona and the cities of the East, such as those of Turkey. While the phenomenon is prominent in the Marches, other Jewish communities display only rare examples of the cylindrical pillar among Jewish tombstones.

We shall now discuss the persecutions, the expulsion of the Jews and the new hygienic and sanitary laws at the end of the eighteenth century as reasons for the loss of mașevot and their reutilization as building material

\subsection{Persecution and the expulsion of Jews and the loss of memory}

The history of the Italian Jewish cemeteries, as of the Jews themselves, has been strongly affected by the persecution and expulsions experienced by the Jews. To give an example, if the Jews had a rich and beautiful cemetery, and were expelled from the city in which they lived, they were forced to abandon it. In such circumstances, normally the mașevot were lost to the Jewish community, either being reused by Christians for other purposes, or even re-written on the reverse for the Christian dead.

An example of the abandonment of a cemetery is that of the important Jewish community in Bologna under the rule of the Papal State, which, after centuries of pacific coexistence with the Christians, was expelled in 1569. Many Jews took refuge in the nearby city of Ferrara, still under the benevolent rule of the house of Este. We know that their cemetery was bought by the nuns of St. Peter Martyr, and that most of the tombstones were lost or sold for secondary use. Only a few tombstone of the rich Jewish bankers of Bologna survived, and they are now kept at the Medieval Museum in Bologna. One of them, that of Yoav Șeruya from Rieti, who died in 1547, was re-used twenty-four years later to mark the burial place of the Christian Rinaldo Duglioli (Fig. 20). His son, Albizio Duglioli, bought from the Sisters of St. Peter's a marble headstone 

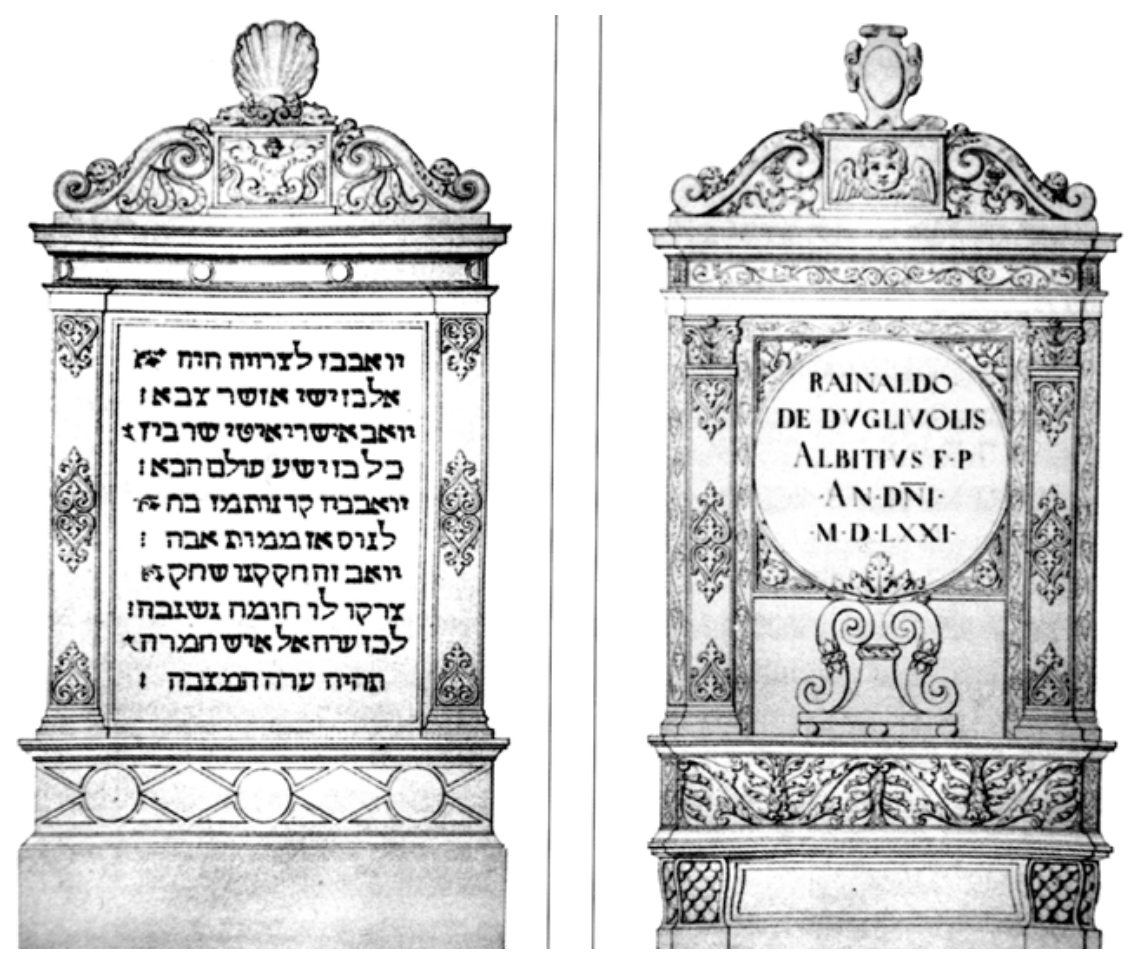

Fig. 20: A picture, depicting both the original front side tombstone of Yoav Șeruya from Rieti, who died in 1547, and of the reverse, which was re-used 24 years later, in 1671, to mark the burial place of the Christian Rinaldo Duglioli; from the book Eletta dei monumenti più illustri e classici, published in Bologna in 1840, vol. 2.

with a large thickness. It was cut in the thickness direction, leaving about twothirds for a new peace of marble to be engraved, and separating the original side written in Hebrew, which had broken during the cutting process. Recently this tombstone was examined with an Enhanced Compton Spectrometer, scanning it with an electronic microscope. ${ }^{20}$ Also, the remarkable tombstone of Avraham da Fano, a rich banker who died in Bologna on 24 Tammuz 1508 (see Fig. 16), was re-used 152 years later in 1660 for engraving on the reverse side of the marble the Latin epitaph of the tomb of Carlo De Tassis (Fig. 21). and his wife Anna Linder. Today, this beautiful funerary stone is mounted on a pivot so that the visitor can rotate and view the two sides, the Hebrew and the Latin (Fig. 22).

20 G. Maino (ed.), Antichi marmi e nuove tecnologie. La lapide di Yoav da Rieti nel Museo Civico di Bologna (Torino, London, Venice, New York, Turin: Umberto Allemandi, 2007). 


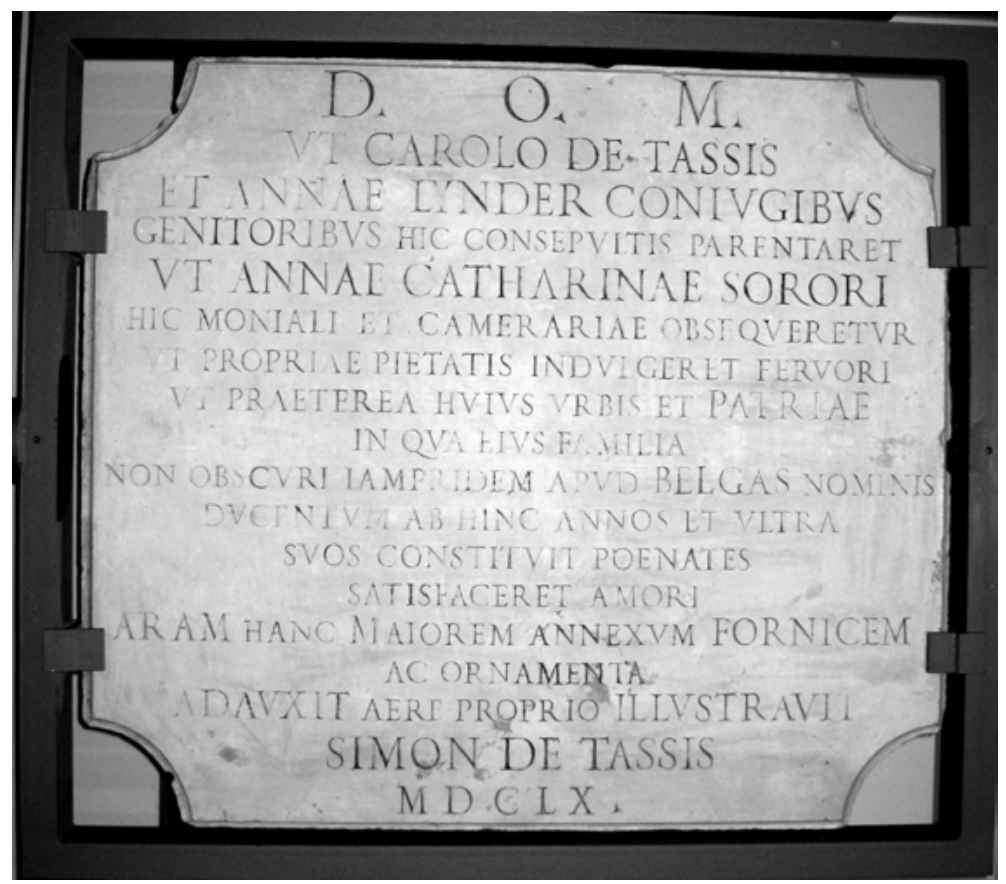

Fig. 21: The tombstone of Avraham da Fano, a rich banker who died in Bologna on 24 Tammuz 1508 (see fig. 16). In 1660, some 60 years after the expulsion of the Jews from Bologna in 1569 and 152 years after the death of Avraham, the stone was re-used for a Christian tomb on which is engraved on the reverse side of the marble the Latin epitaph of Carlo De Tassis and his wife Anna Linder.

The re-use of the stone and marble of tombstones was a normal practice all over the world. Some of the ancient massevot from the twelfth-fourteenth centuries now kept in the Nachmanides Museum of Gerona were found in a building not far from the old Jewish cemetery. A dedicatory stone with the inscription of the donor was re-used as building stone in the synagogue structure of Syracuse when it was transformed into the Church of San Giovannello (Fig. 23). Some sepulchral inscriptions from Matera (southern Italy) dating back to the ninth century, were re-used as building elements, as evidenced by seven holes $^{21}$. In Venosa, many tombstones of the same period were bricked into the walls of the church of the Holy Trinity. The examples could continue. The

21 C. Colafemmina, Tre iscrizioni ebraiche altomedievali a Matera, in M. Perani (ed.), Una manna buona per Mantova. Man Tov le-Man Tovah. Studi in onore di Vittore Colorni per il suo $92^{\circ}$ Compleanno (Florence: Olschki, 2004), pp. 101-14. 


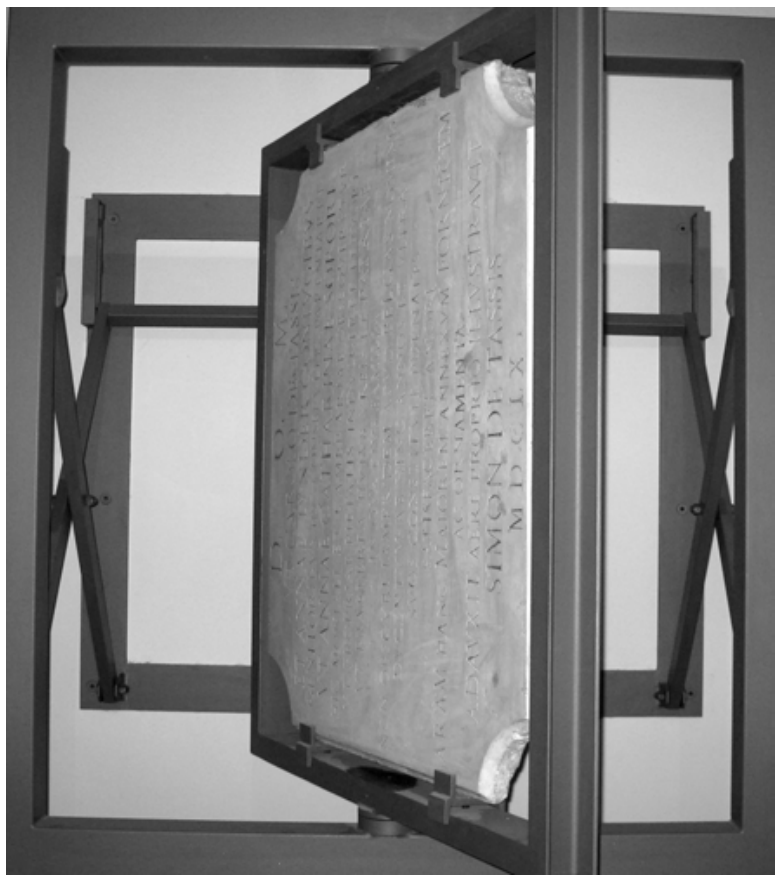

Fig. 22: Today the beautiful tombstone, formerly of Avraham da Fano (front side, see fig. 16) and later of the De Tassis family (reverse side), is mounted on a pivot so that the visitor can turn the two sides, and see both the Hebrew and the Latin.

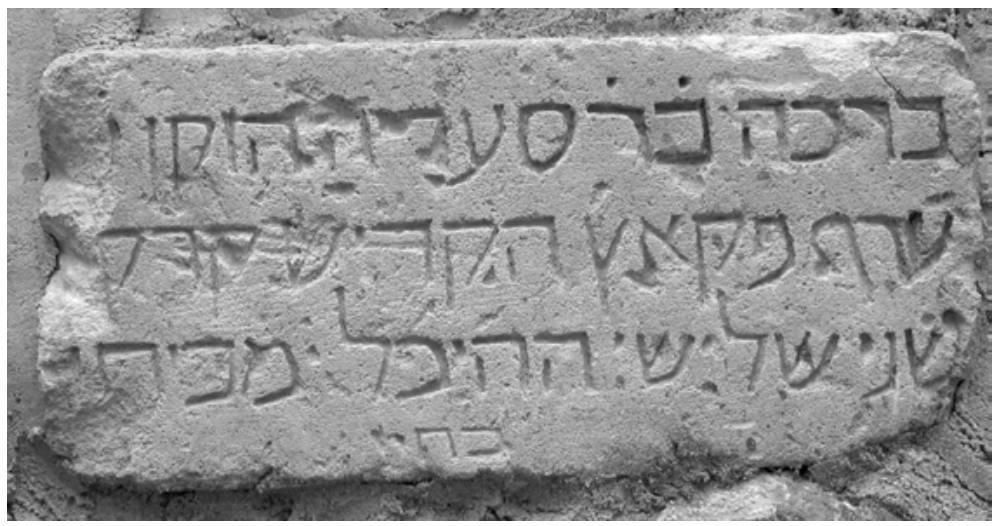

Fig. 23: A dedicatory stone of the $15^{\text {th }}$ century, with an inscription about the donor who gave a piece of ground for the enlargement of the synagogue at Syracuse. After the expulsion of the Jews from Sicily in 1492, when the synagogue was transformed into the Church of San Giovannello, the inscription was re-used as a building stone in the apse of the church. 
Nazis also re-used the tombstones of the ancient Jewish cemetery of the 'Remu' in Krakow to pave the streets after cutting into two parts those that that were too large for this. After the Second World War many of them were recovered and partially restored.

Since ancient times Egyptian papyri have been re-used to make pasteboard for the mummies or to function as packaging for goods. Parchment and skin, first used as to record writing and then recycled as bindings, ties, belts or straps; in addition, sheets of paper with handwriting, when no longer interesting as texts, were glued together to make fillings for the binding of books, just to give some examples. There is no doubt that in the history of civilization, the re-use of materials for secondary, cultural purposes represented a major element in their conservation.

\subsection{The new hygienic and sanitary laws of Europe at the end of eighteenth century and the dispersion of Jewish tombstones}

In 1804, with the Edict of Saint-Cloud, Napoleon Bonaparte imposed on the lands of his empire, including the Italian regions under his rule, the displacement of cemeteries to sites outside the populated centres. This legislation, requiring the construction of cemeteries outside the town, derived from both a hygienic consideration and from a Jacobin egalitarianism, and it ordered not only that the tombs should be located outside the town but also that they should have similar stones. The extension of the edict to Italy also aroused controversy and discussion, in the course of which the poet Ugo Foscolo intervened with the composition of his work I sepolcri, 'The tombs'.

But as far as Mantua was concerned, already some time before, in the eighties of the eighteenth century the Emperor Franz Joseph of Austria imposed on his domains of the Lombardo-Veneto these new hygienic rules. So in the town surrounded by three lakes formed by the River Mincio, both the Christian and Jewish communities were forced to move their cemeteries outside the town. The Jews of Mantua, after several attempts to find a suitable area for the new cemetery made between 1786 and 1789, finally succeeded in finding a suitable field and in January 1790 they began to bury their dead in the new area outside the San Giorgio port, where the cemetery is located up to the present. However, according to Jewish religious law, the dead are not usually removed from their place of burial, and consequently for a while even the old cemetery continued to be guarded. But over the years it was abandoned, and those tombstones that were beautiful from the artistic point of 


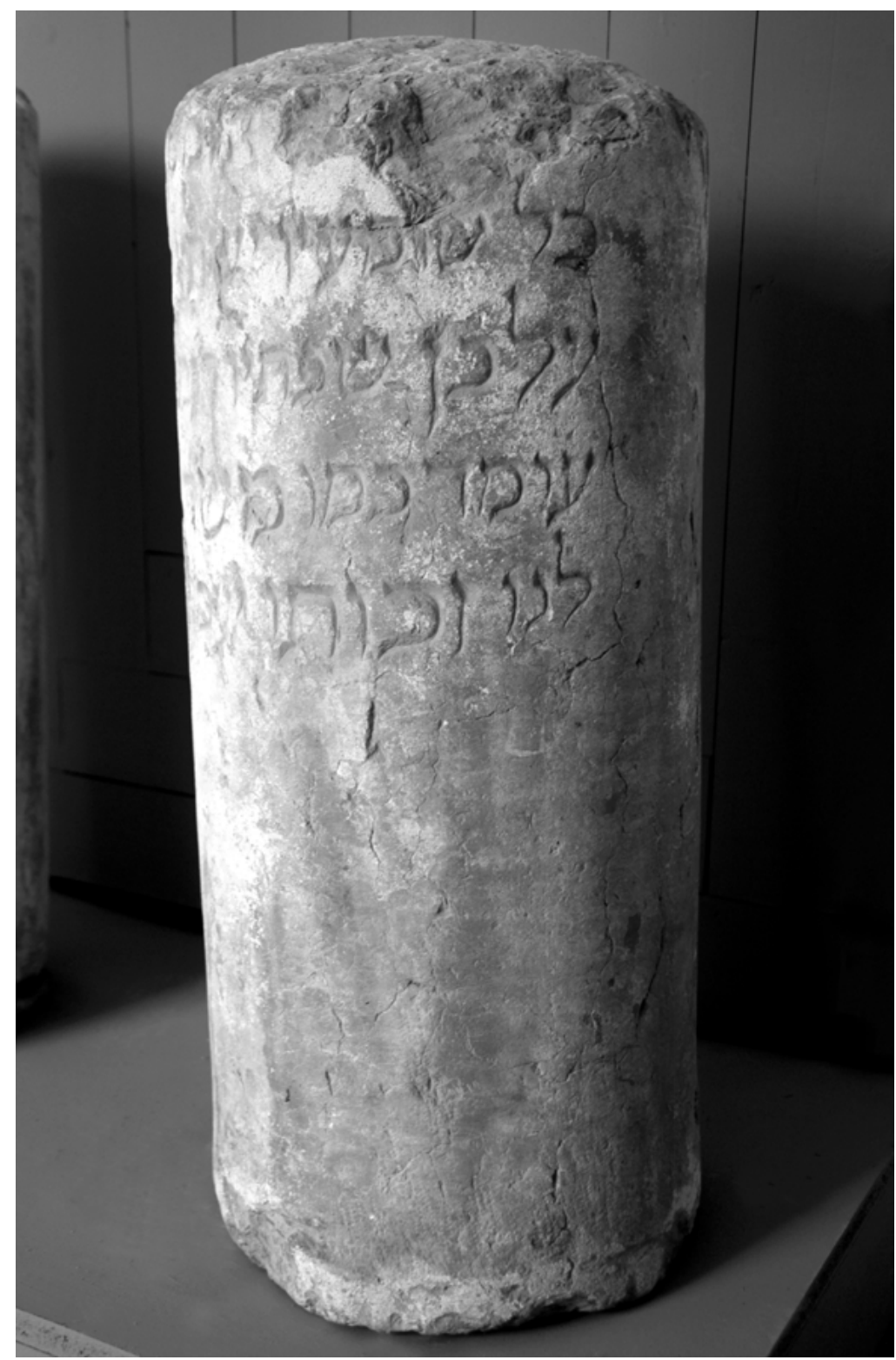

Fig. 24: The funerary cylindrical pillar, engraved in beautiful Sefardi letters, of the famous Mantua kabbalist, Moshe Zacuto, chief rabbi of Mantua from 1673 until his death on 1 October 1697. Mutilated on two-thirds of the upper part, it had been used as building material before being purchased by Vittore Colorni and Shlomo Simonsohn and brought into the Jewish cemetery. It was later lost but recently rediscovered by the author in the Diocesan Museum of Mantua, where it had remained unidentified. 
view or more valuable for the literary texts and poems of their inscriptions generally those of the most important personalities of the community, such as rich bankers, learned and famous people and educated rabbis - were transported to the new cemetery of St. Giorgio.

That area was, however, a strategic point for military defence, and a few years later, during the Austrian wars with the French, the Jews had to move back to the place in which they had formerly buried their dead. Later, under Napoleonic rule in 1802, they returned permanently to the new cemetery. In this period the Jewish community of Mantua buried sixty of its dead each year. In 1816, the walls in the new cemetery collapsed and for a short time the Jews were again forced to bury their dead in the old area of the district of Gradaro, near the church of San Nicole. These constant shifts obviously led to the loss of many tombstones. After the Jewish cemeteries had been definitively abandoned, the abundant marble tombstones became a free quarry for non-Jews who required a marble slab for one purpose or another. In a house in Mantua (see below), in which a tombstone from the eighteenth century is now the base of a barbecue, there are also fragments of other tombstones with epitaphs in Hebrew that have been re-used as paving in its courtyard (Fig. 24). All these factors, together with the problematic historical context, explain the loss of most of the Italian Jewish tombstones of the ancient cemeteries from the period ranging from the sixteenth to the end of the eighteenth centuries, before the application of the new sanitary regulations of the Austrian and French rulers in northern Italy. We shall now examine two re-used mașevot from Mantua.

\subsection{The cylindrical funerary pillar of Moshe Zacuto (d. 1697)}

An amazing story about the re-use of a tombstone concerns the cylindrical pillar of the famous Mantua kabbalist Moshe Zacuto (Fig. 25), who was the chief rabbi in Mantua from 1673 until his death on 1 October, 1697. This funerary pillar is unfortunately mutilated in more than two-thirds of the upper part. Born in Amsterdam in 1639, Zacuto studied in the rabbinical academies of Eastern Europe and left Venice in 1645 for appointment as rabbi of Mantua. He wrote extensively in the fields of Hebrew learning, law, poetry and esoteric kabbala, and in Mantua he introduced a group of disciples, notably Yehuda Briel and Aviad Sar Shalom Basilea, to kabbala. Thanks to Dvora Bregman, all his poetry is now published, and she has also written about the epitaphs that 


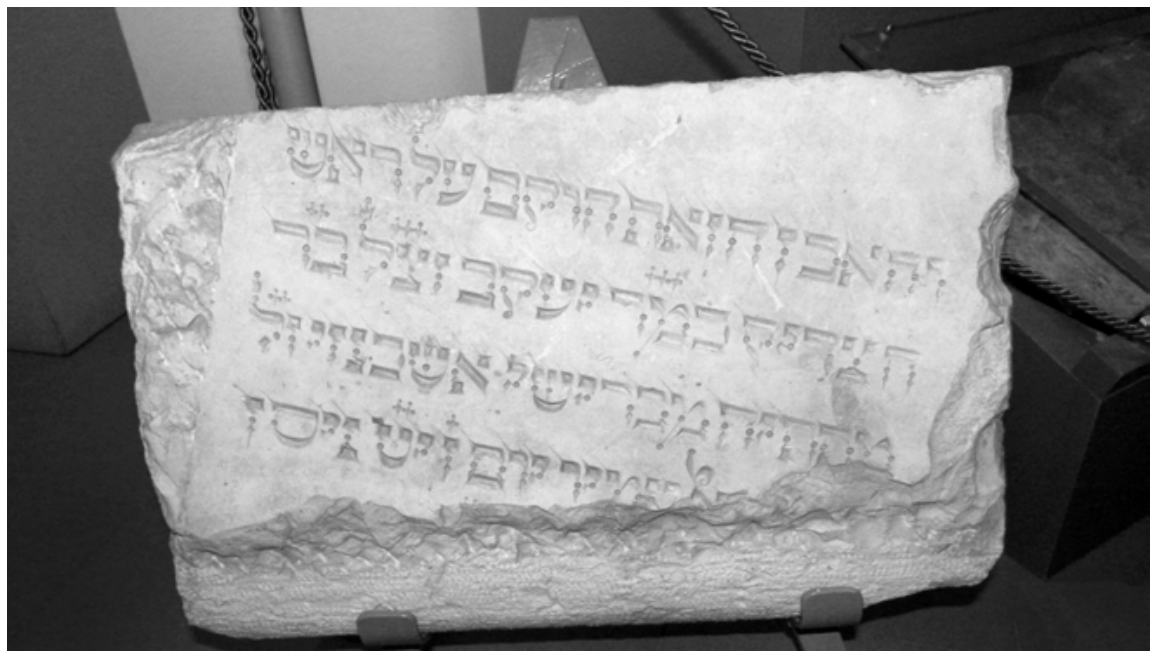

Fig. 25: Tombstone of Ya'aqov ben Matitya Ashkenazi from Brescia, in the magnificent stile gemmato, probably from the beginning of the $16^{\text {th }}$ century, held in the Museum of the Jewish Community of Ferrara. In its epitaph we read: והאבן הזאת הוקם על על ראש /

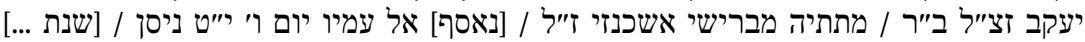
English version: This stone was erected at the head of the righteous, $R$. Ya'aqov, the memory of the righteous be a blessing, son of Matitya from Brescia Ashkenazi, of blessed memory, gathered to his people on Friday 19 Nisan [of the year ...]. The final lacuna is because secondary use had been made of the stone.

he himself composed.22 During S. Simonsohn's studies in Mantua in 1952/53 he and Vittore Colorni found in Mantua, in a shop selling building material not far from the cemetery, the cylindrical pillar of Zacuto, already mutilated but not as it is at the present. They bought it, in order to transfer it to the Jewish cemetery in Mantua. But when I recently researched the tombstones of that ancient cemetery of Mantua, it was missing. The stone had previously disappeared in the second half of the nineteenth century, when Abba Appelbaum, author of a book on the kabbalist (Moshe Zakut, published in Lvov in 1926), had asked the chief rabbi of Mantua, Marco Mortara, for the tombstone of Zacuto, and Mortara had said that it was lost. During my researches in 2007, I was informed that the Diocesan Museum of Mantua possessed two funerary Hebrew cylindrical pillars in Hebrew. I went to check these and fortunately rediscovered Zacuto's mutilated tombstone. Another cylindrical pillar, found in Mantua, had been re-used to act as a support of the missal in a Catholic

22 D. Bregman, I Raise my Heart: Poems by Moses Zacuto (Hebrew; Jerusalem: Ben Zvi, 2009), pp. 8, 367-434, and her Hebrew article 'Dimness and Clarity in Tofteh Aruch by Rabbi Moses Zacuto', Pe'amim, 96 (2003), pp. 35-52. 


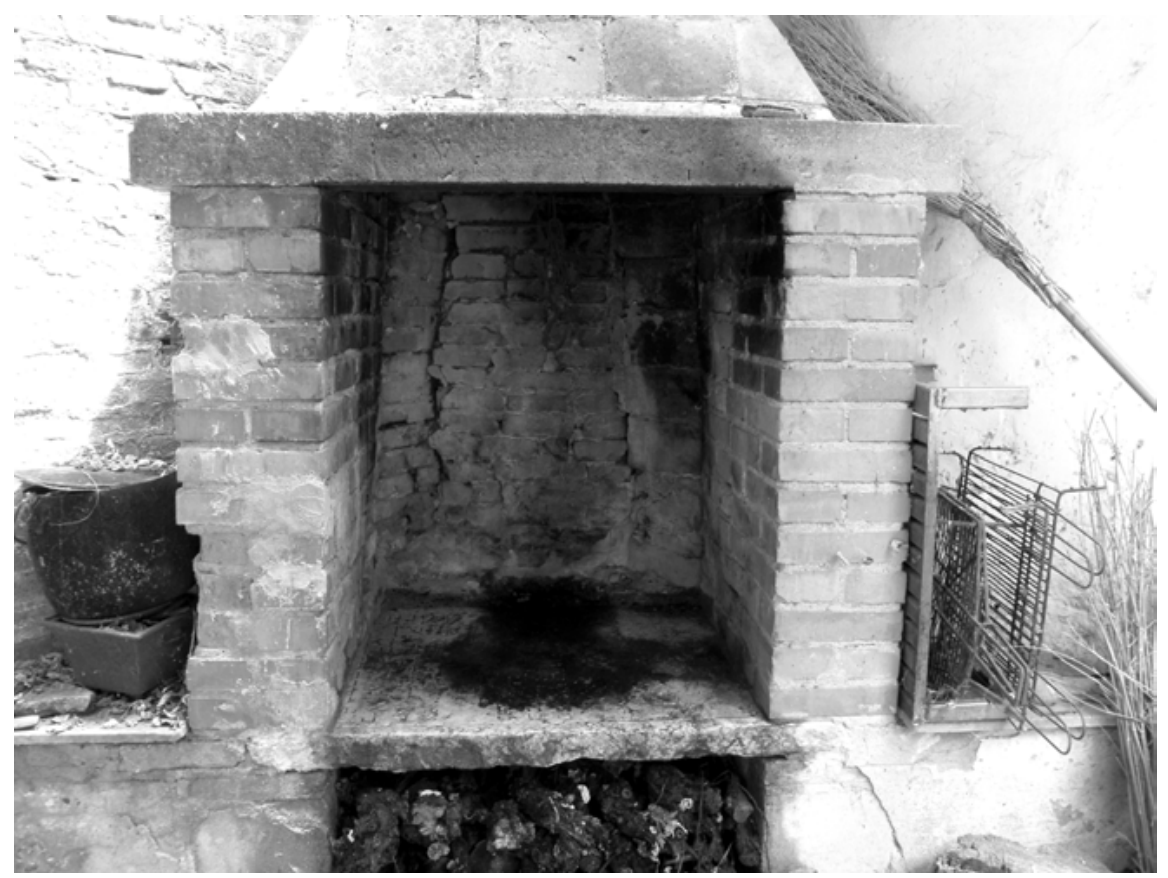

Fig. 26: The wrongly written and consequently unfinished tombstone of Ya'aqov Ḥayyim dalla Volta, who died in 1735. It was re-used in 1950 as the base of a barbecue in a house located in what had once been the area of the old Jewish cemetery of Mantua.

chapel in a village near Mantua (Fig. 26). The text surviving at the bottom of the pillar contains only the last four lines out of a total of thirteen and is presented below. The first lines are in prose, and contain the information about the death of the leading kabbalist. There follows an ottava rima ending in $\mathrm{AB}$ $\mathrm{AB}$ AB CC, with A - $u$, B -ver and C -hah.

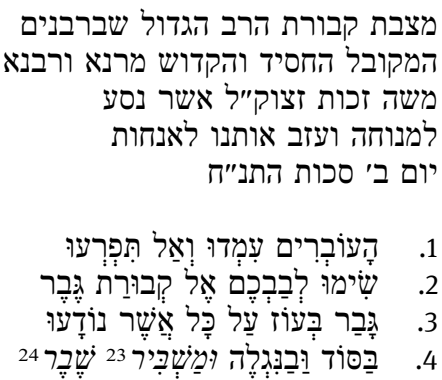

23 Prov 11:26.

24 Gen 42:1-2. 


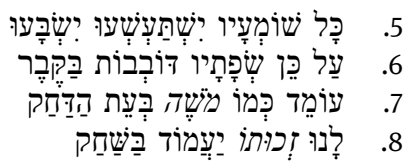

\subsection{The wrong and consequently unfinished tombstone of Ya‘aqov Hayyim Dalla Volta (d. 1735)}

On July 26, 2008, I went to Mantua to visit the location of the ancient Jewish cemetery, in the Gradaro quarter of the city, where the Jewish community buried its dead from its foundation until the end of eighteenth century. I had been informed of the existence of a maseva which had been re-used in 1950 by the owner of an house as the base of a barbecue (Fig. 27). The precious fireplace obtained by re-using a seventeenth-century tombstone was located at vicolo Maestro no. 10, in Mantua. Having arrived there, I started to clean the upper part of the stone, on to which had been engraved the Hebrew text of a epitaph

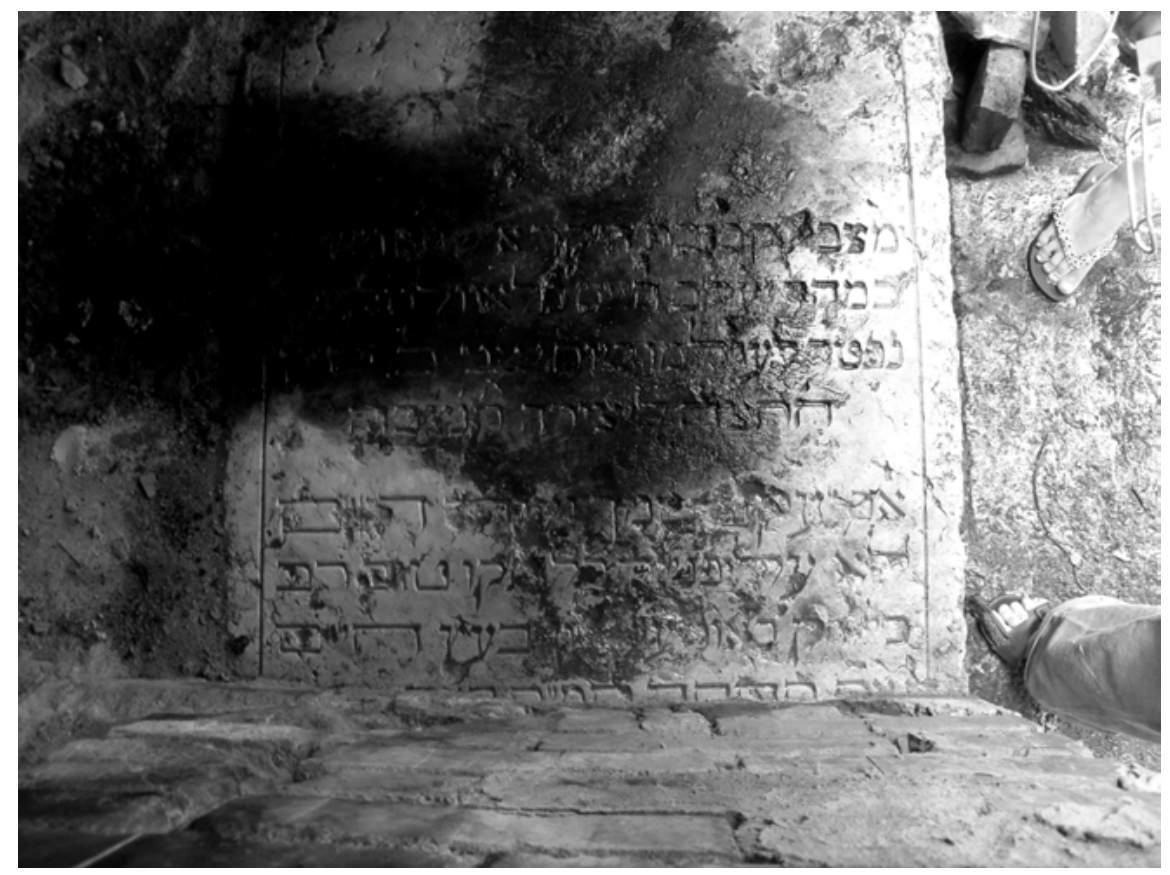

Fig. 27: Detail from the text on the epitaph of the tombstone of the Mantua Jewish pharmacist Ya'aqov Hayyim Dalla Volta (from Volta Mantovana in Mantua Province), unfinished because the engraver erroneously sculpted qevuvat instead of qevurat. 


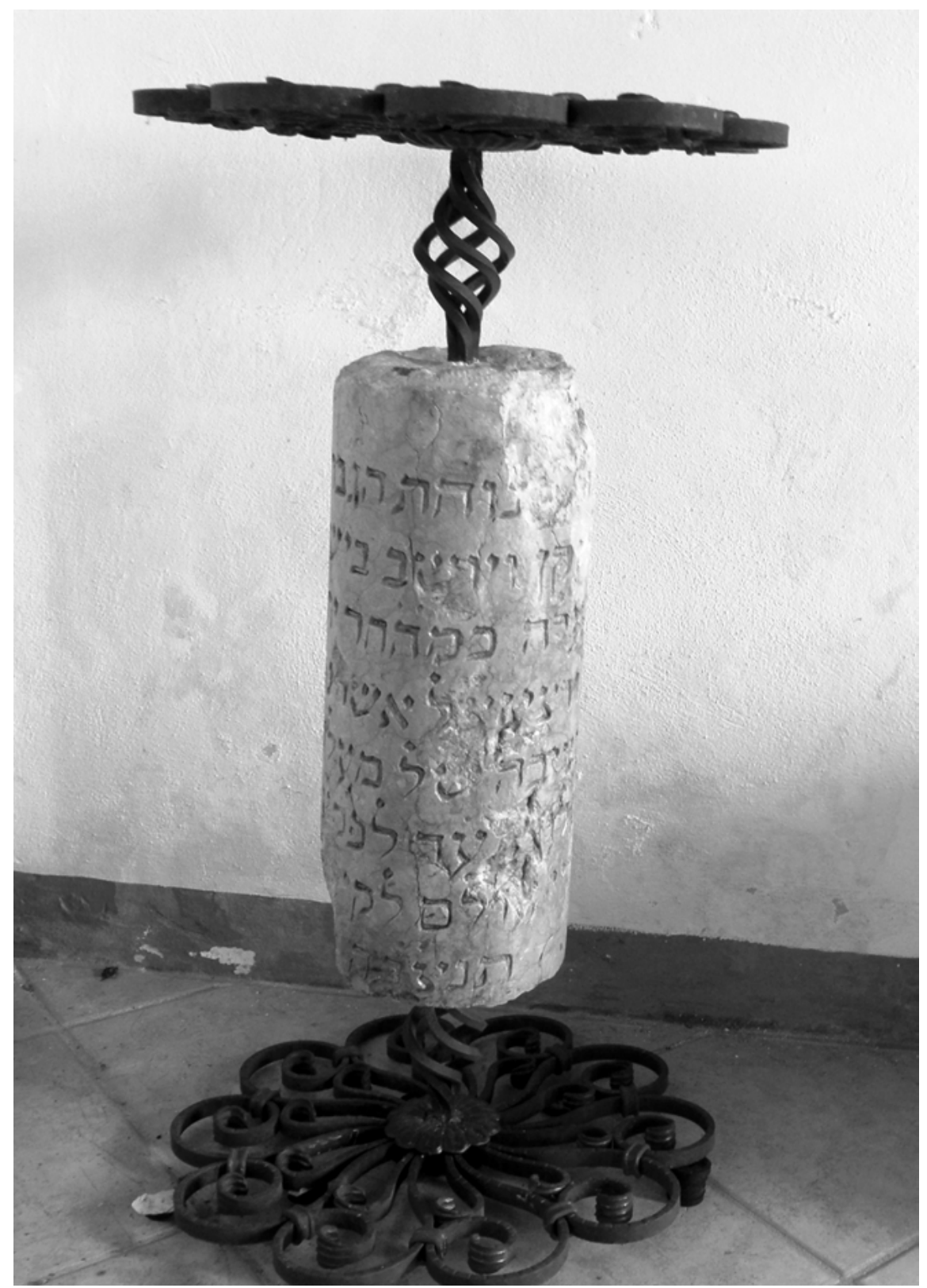

Fig. 28: The cylindrical pillar, found recently in Mantua, which had once been the tombstone of Yehoshua ben Mahalalel Norsa, banker in Mantua where he died on 16 December 1713. It had been re-used as a support for the Gospel volume in a Catholic chapel in a village near Mantua. 
(Fig. 28). When the marble was cleaned, I could read the text, starting on line 1 with a standard formula commonly used in epitaphs:

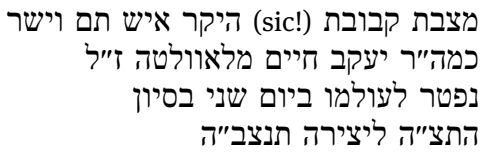

Ya'aqov Dalla Volta died on 2 Siwan of the Jewish year 5495 which, according the Gregorian Calendar, was 23 May of the Christian year 1735. Finally, the last four lines, in rhyme and rhythm, also became legible. This part, celebrating the virtues and the goodness of the dead, was written in poetry, according to an alternate rhyme scheme: A-B, A-B, in which $\mathrm{A}$ ends in -im and B ends in -ov. The Hebrew text of the tombstone reads:

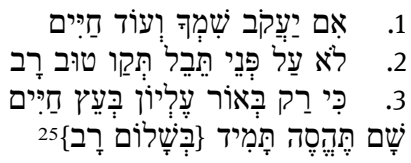

The poem has ten syllables, alternating rhymes, and metrical structure that twice has two long vowels followed by a short and long, and then two long vowels (mahir).

English version:

Prose part:

Tombstone of the dear right and perfect man (Job 1:1) / the honoured R. Ya'aqov Hayyim Dalla Volta, may his memory be blessed, / who died on 2 Siwan / 5495 of the creation, may his soul be bound in the bundle of life. /

Poetic part:

If Ya'aqov is your name and, in addition, Hayyim, / not on the face of the earth can you expect great good, but only in the light of God and in the tree of the life / there you will find refuge forever in an everlasting peace.

\section{Comment:}

I was surprised to see that the engraved text of the epitaph started from about the middle of the mașeva, leaving the upper part unwritten and unfinished. This appeared to me fairly strange. Perhaps the engraver had intended

25 The last two word are not completely legible, being partially walled in, and consequently they are conjecturally reconstructed, according to rhyme and rhythm requirements. 
to add in the upper part a decoration, an ornamentation or even a family stemma. If so, why he did not finish his work? After these considerations, I realized that the word for sepulchre in Hebrew qevurat, was wrongly engraved as קבורת instead of the correct. I found it difficult to believe that such an error had been made but finally accepted that the engraver had written a bet instead of the required resh. At that point I imagined the scene. Normally in Italy the engraving of mașevot was not done by Jews, but by Christian artisans who obviously did not know Hebrew, but only knew the shape of the Hebrew letters, after having sculpted them for years. The engraver who prepared the tombstones for the deceased of the populous Jewish community of Mantua, which at that time numbered about two thousand people, had his shop next to the cemetery. He engraved the inscriptions by copying a model prepared by a rabbi or by a learned member of the community capable of composing poems in rhymes. After he had finished his work, he called the relatives to choose what they wished to place in the upper part of the maseva as an element of ornamentation or a family stemma. When, in this case, the relatives of the deceased arrived, they read the inscription and noticed the mistake qevuvat in the text. Of course it was unfeasible to repair the error. It would have been easy to transform a resh into a bet adding a horizontal line at its base, but it was simply impossible to do the opposite and correct a bet into a resh. Consequently, the only solution was to engrave a new tombstone with the correct text. So the upper half of the incorrectly engraved tombstone remained unfinished and, as a consequence, it was never placed in the cemetery to mark the tomb of the rich Mantua pharmacist, Ya'aqov Dalla Volta. A new tombstone with the correct text was engraved and placed in the cemetery, but it was lost together with the majority of the sepulchral inscriptions. Our wrong mașeva was stored in the engraver's shop, in the hope that it could at some stage be used for a new different inscription on the reverse side and placed in a wall. But this never happened, and it was abandoned on that site from 1735 until 1950, when Mr Rodolfo Grizzi bought the house and its garden where the engraver's shop had been, and re-used it as a basis for his barbecue.

To conclude, significant work remains to be done in order to save this precious Jewish heritage (Figs. 29 and 30), and it is of enormous importance to transmit to future generations the memory contained in these stones. ${ }^{26}$

26 The author of this article is deeply grateful to Professor Dvora Bregman and Professor Yaakov Bentolila for their important assistance with the transcription, presentation and pointing of the poetic texts cited above. 


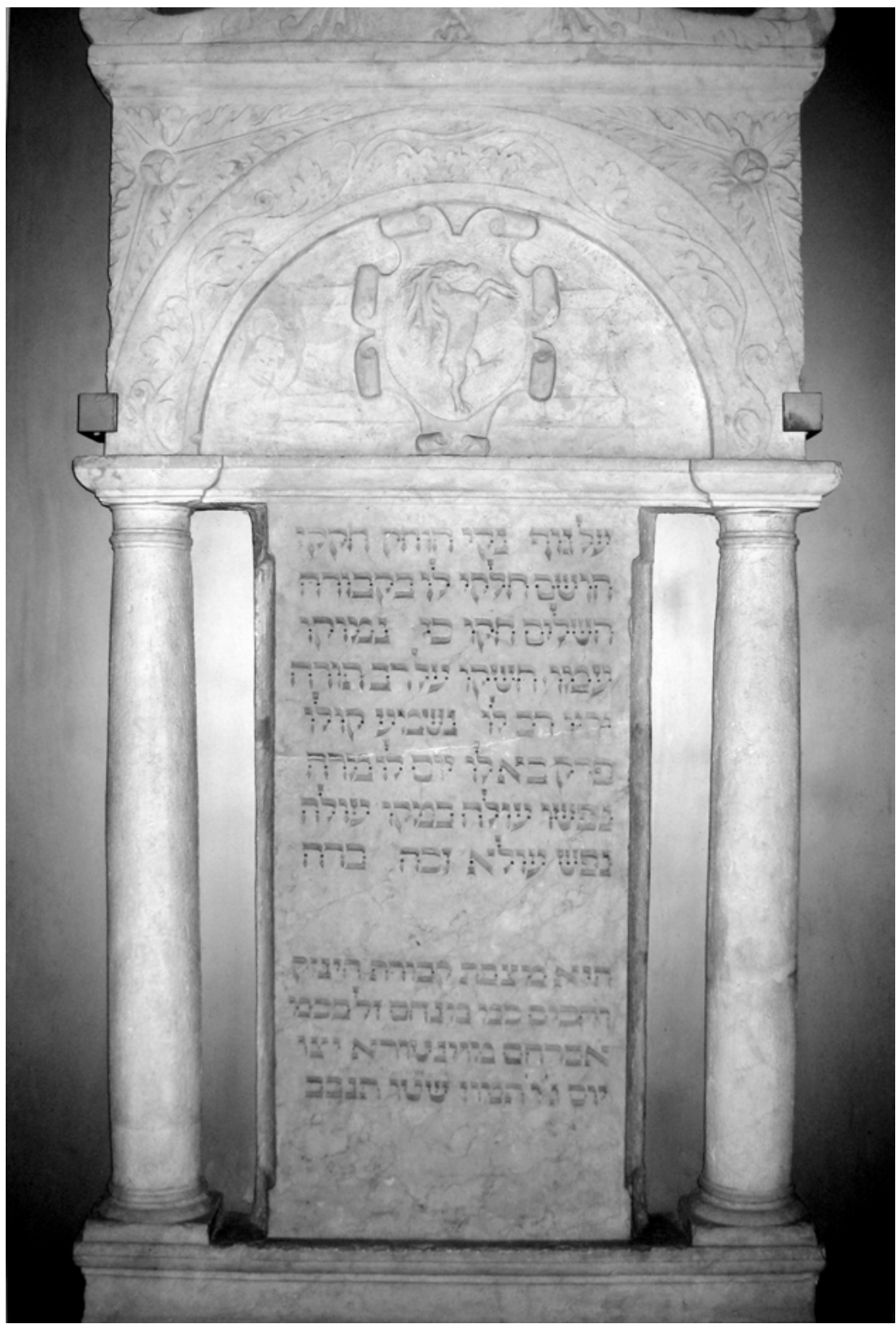

Fig. 29: The tombstone of Menahem ben Avraham da Ventura, Jewish banker in Bologna where he died on 3 Tammuz 1555; sculpted in the magnificent style of the Renaissance and of the humanistic Zeitgeist of the mid- $16^{\text {th }}$ century, the tombstone is kept in the Medieval Museum of Bologna. 


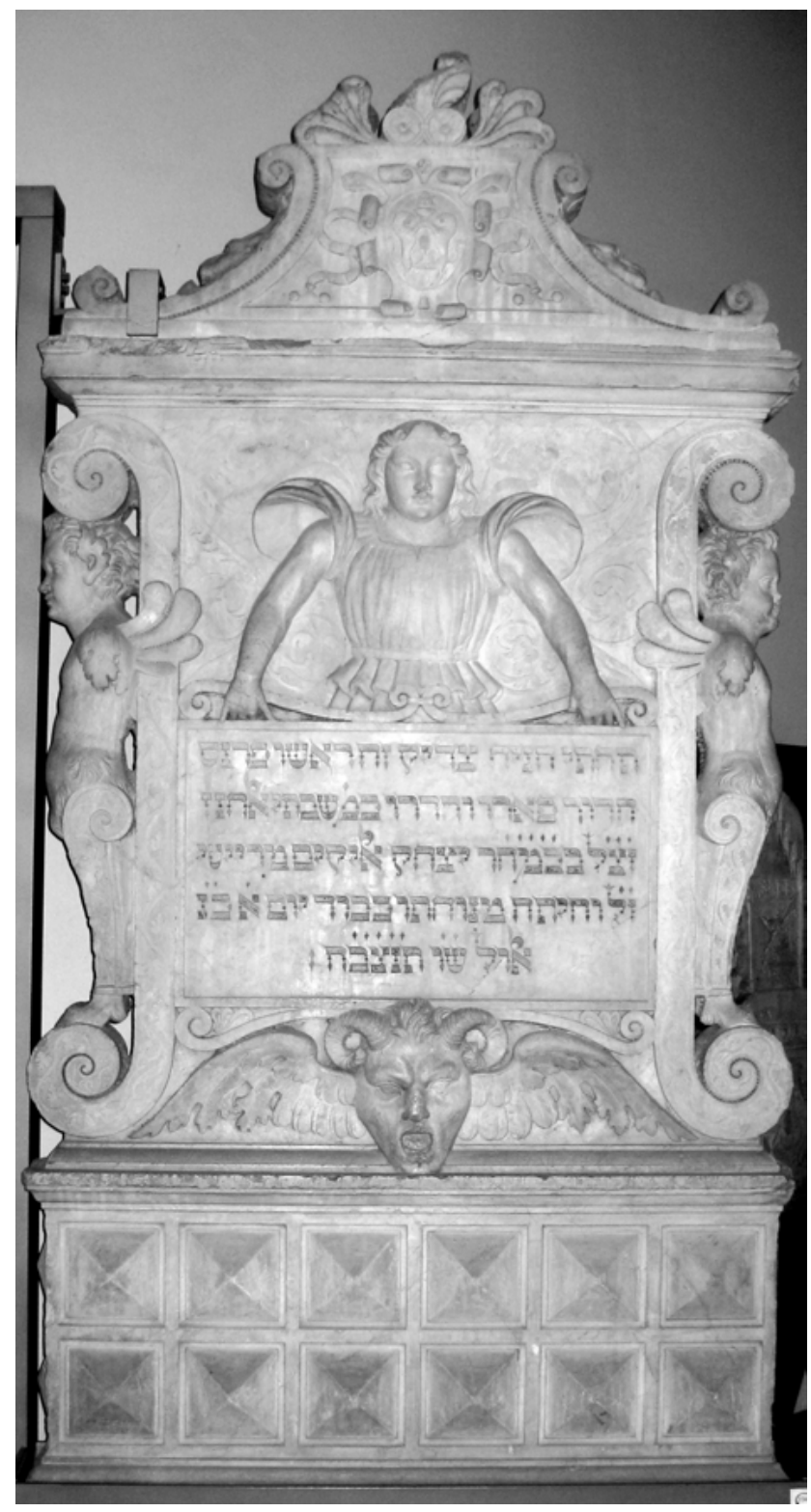

Fig. 30: The tombstone of Shabbetai Elhanan da Rieti, a leading Jew of Bologna, who died on Monday 23 Elul 1546, in the monumental style of that period with angels and fantastic figures. The large blocks in the lower part perhaps evoke those of the western wall in the Herodian basement of the Temple in Jerusalem, depicted in funerary monuments according to a style that is also found on some Italian mașevot in subsequent centuries. The tombstone is kept in the Medieval Museum of Bologna. 